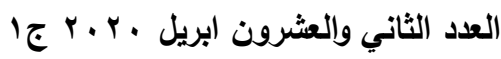

المجلة العلمية لكلية التربية النوعية

\title{
الخطاب الدرامي في مسرع أنس داود الشعري للطفل وأثره على بنية النص
}

\author{
د/ نهى جلال مندور \\ مدرس بقسم الإعلام التربوي كلية التربية \\ النوعية -جامعة المنوفية
}

\author{
أ.د / محمد إبراهيم شيـحة \\ أستاذ الدراما والنقد المتفرغ - بالمعهد العالي للفنون \\ المسرحية- أكاديمية الفنون
}

$$
\text { مدرس أحمد محمد شديد }
$$

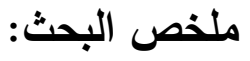

تنتاول هذه الدراسة واحدة من التجارب الفنبة الغنية في مجال أدب الأطفال، وهي تجربة

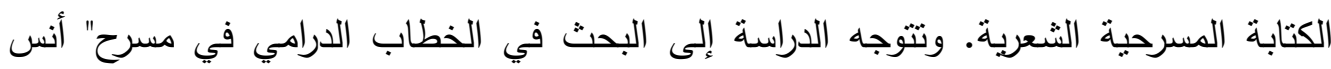

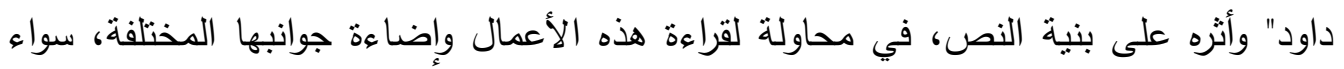

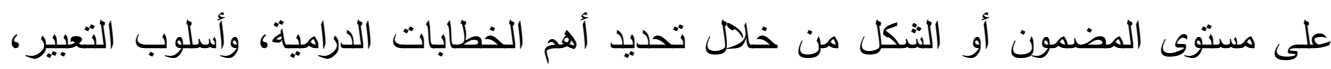

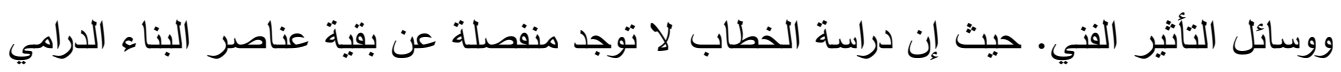
الأخرى. واعتمد البحث على المنهج الوصفي التحليلي في تتاول المسرحيات الثعرية المنشورة

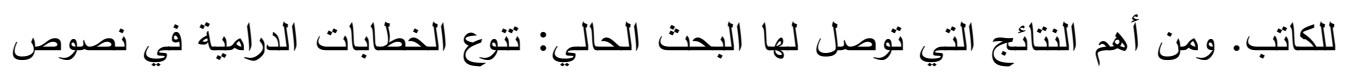
داود بين القومي والتربوي، وقد انعكس ذللك التتوع على بنية النص لديه.

\section{Summary Of the Study:}

This study focuses on Poetic theatre as being one of the most precious literary experiments in the field of children literature. The study is concerned with investigating the dramatic discourse in the plays of( Anas Dawoud) and its influence on the structure of the text in an attempt to read these plays and to shed light upon their various sides, whether on the level of content- through illustrating the main dramatic discourse- style or different means or literary effects. This because the study of discourse is inseparable from the other dramatic elements. The research depends on the analytical descriptive methodology in discussing the writer's published plays. The most important outcome of the study is the variation of dramatic discourses between the national and the didactic in a way that affected the structures of his plays. 


\section{مقدمة البحث:}

مسرح الطفل هو أحد أهم وسائط أدب الطفولة في العصر الحديث؛ فهو وسيط مركب العناصر يتوجه لمرحلة عمرية مهمة ومتدرجة هي مرحلة الطفولة، ويتمايز عن الوسائط التقافية

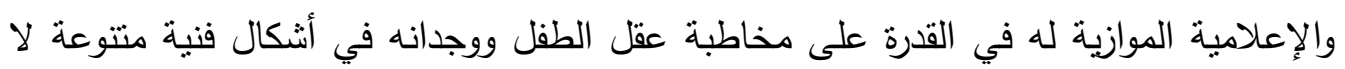
تتوافر عناصرها في الوسائط الأدبية الأخرى. والمسرح الثعري بخصوصيته الفنبة واللغوية

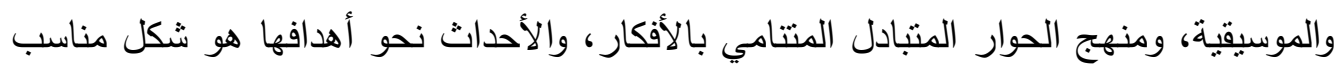
لتحقيق مجموعة من الإيجابيات المنصلة بخصائص الطفولة؛ فالثعر أسبق الفنون إلى وجدان الطفل باعتبار أن الثعر موسيقى يحمل الكلمات. ويؤكد علماء النفس أن الصياغة الشعرية (المغناة) تبقى في وجدان الأطفال وذاكرتهم فترة طويلة. وتتير الدراسات المهتمة بشئون الطفل

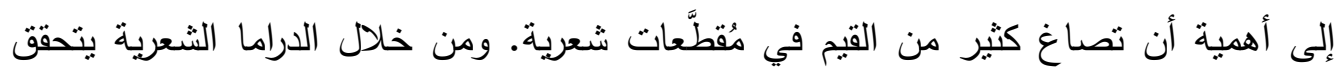
الكثثر من الأهداف المؤثرة في سلوك الطفل؛ حيث يؤدي المبدعون دورًا حيويًا في تشكيل وجدان الأطفال وقدراتهم الإبداعية، وتتمية الحس الجمالي لديهر؛ لأن التجربة المسرحية الثعرية

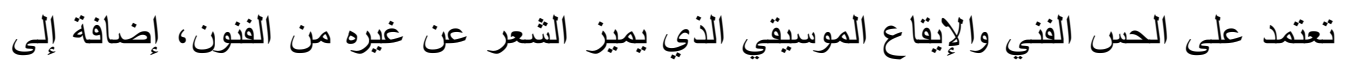

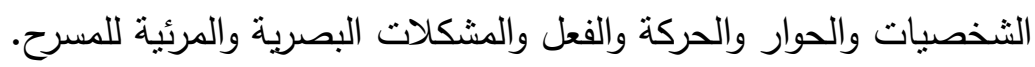

مصر كان لها السبق في تقديم ذلك اللون على يد الثاعر "محمد الهراوي"، فكان لها نصيب غزبر من التأليف في الدراما الثعرية للطفل على يد مجموعة من الكتاب أمثال: إبراهيم

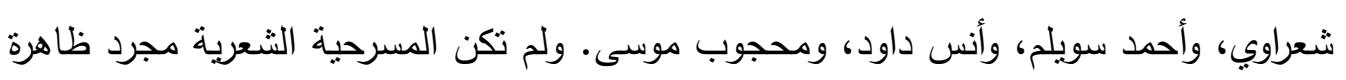

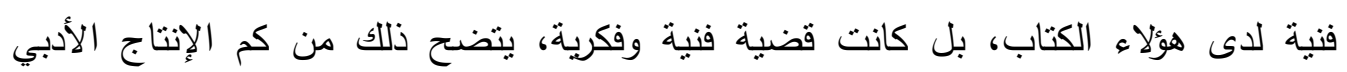

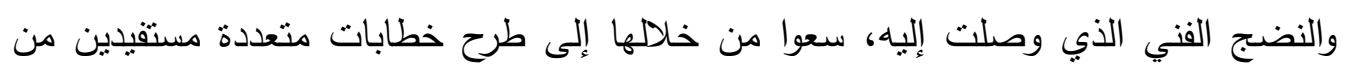
الطاقات الفنية والجمالية والتصويرية للون الأدبي.

ويقوم البحث على دراسة النص دون العناصر الأخرى للمسرحية الشعرية لدى الكاتب

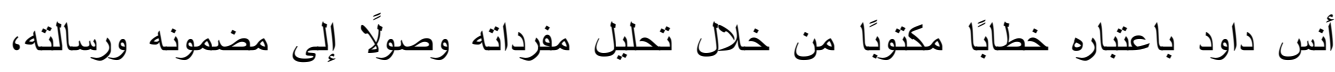

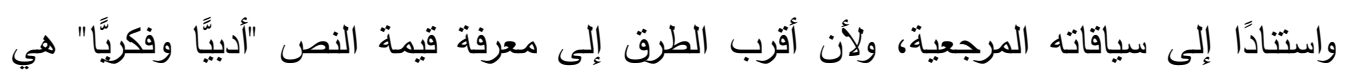

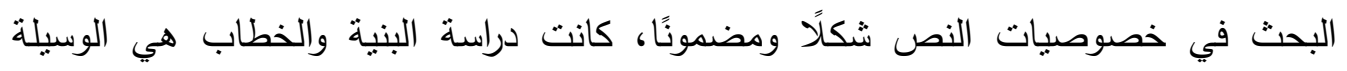
الفُضْلى في استبطان مظاهر أدبية النص الدرامي وقيمته الفنية. 


\section{مشكلة البحث:}

لاحظت الباحثة من خلال البحث في أدبيات الطفولة أن المسرح الشعري الموجه للطفل لم

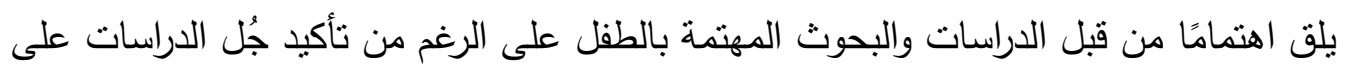

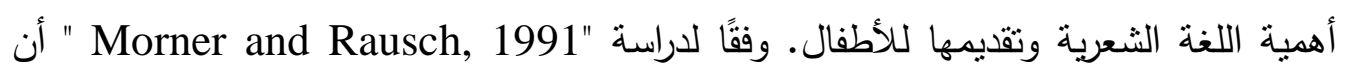
الصورة الفنية للشعر تعني التركيز على المعنى بصورة أكبر من النثر"('). وبنظرة فاحصة إلى ولى الفئ

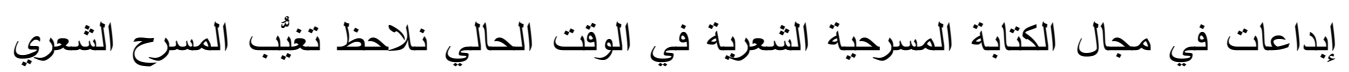

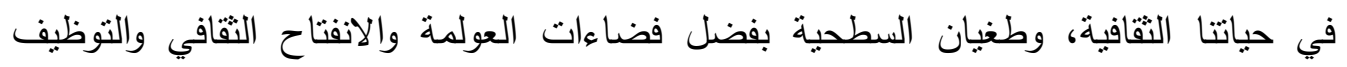

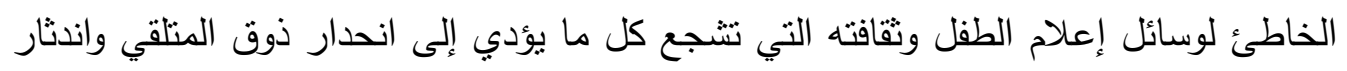
اللغة العربية. وهو ما تبدأ معه حالات الجمود والانحسار في التعبير عن الواقع عبر آليات التعبير، وفي مقدمتها المسرح الثعري. ومما سبق تحددت مشكلة الدراسة في التساؤل الرئيسي

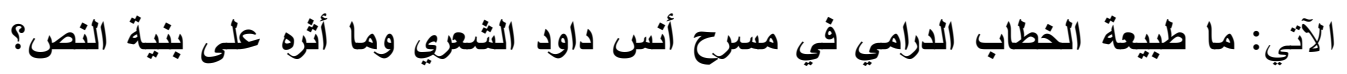

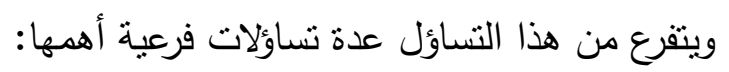

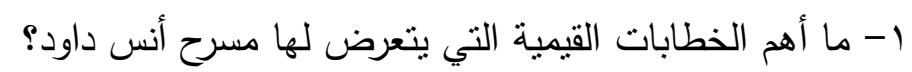

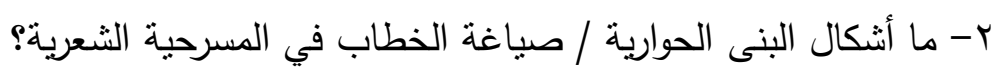

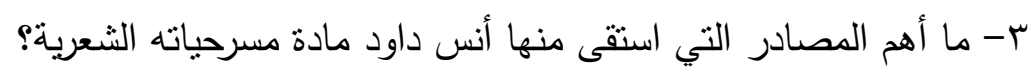

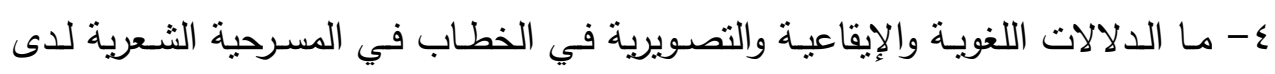
أنس داود؟

ه- ما طبيعة خطاب الثخصية ومرجعيتها في المسرحية الثعرية للطفل؟ ؟- ما آليات البنية الدرامية في المسرحية الشعربة؟ أهداف البحث: يهرف هذا البحث إلى: تهدف الدراسـة الحاليـة إلى التعرف على ماهيـة الخطساب الدرامي في مسرح أنس داود الثعري وأثثر في بنية النص، وذلك من خلال:

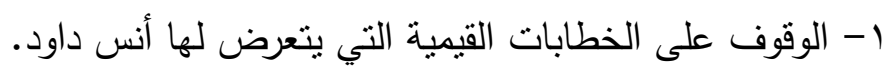

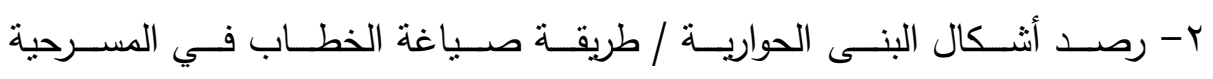
الشعربية للطفل. r- الوقوف على المصادر التي استقى منها داود مادة مسرحيته. 
ع - التعـرف على الــلالات اللغويـة والإيقاعيـة والتصـويرية للخطـاب في المسـرحية

$$
\text { الثعرية. }
$$

0- رصد خطاب الثخصية ومرجعيتها في المسرحية الثعرية.

צ- التعرف على آليات البنية الدرامبة في المسرحية الثعرية.

\section{أهمية البحث:}

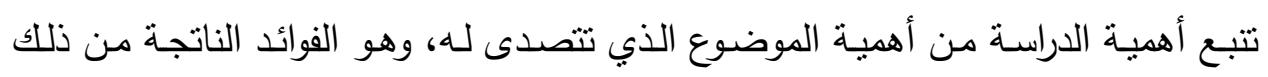
المزج الفني والتربوي بين مسرح الطفل بفنونه والثعر بعوالمه. وتؤكد الدراسات العربية والأجنبية

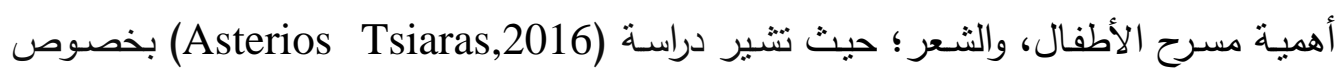

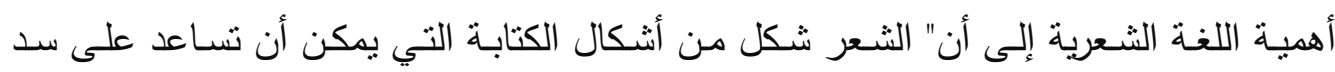

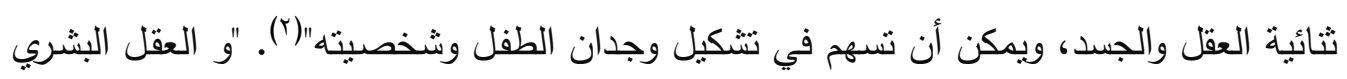

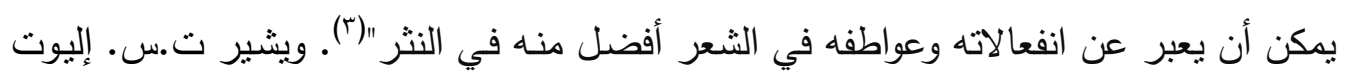
T.S.Eliot التعبير عنهما بالكامل من خلال العامية التي صاغها شعب معين لنفسه عبر نوالي الأجيال..

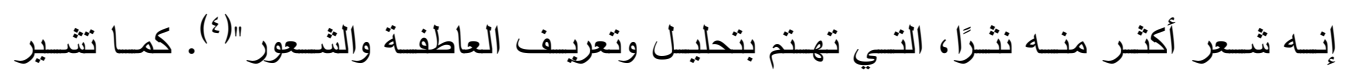
دراسـة Benton,198) إلى أهمية الثـعر في تتمية حب الجمال، حيث إنها يوفر بشكل غير

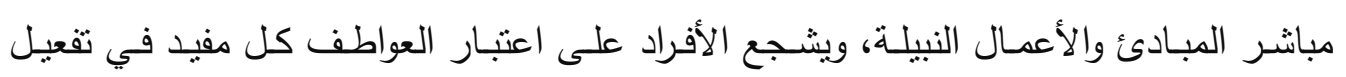

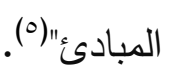

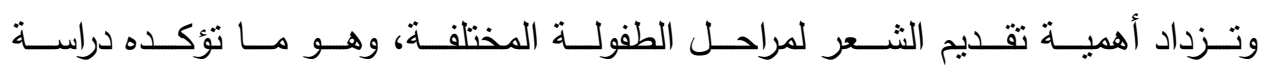

( Goodwyn 1992: Powell,1999) للارتقاء التقافي، مؤكدين أهمية دور المدارس في قيادة الأطفال إلى تقدير تلك الأعمال الأدبية

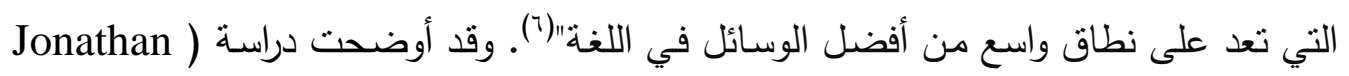

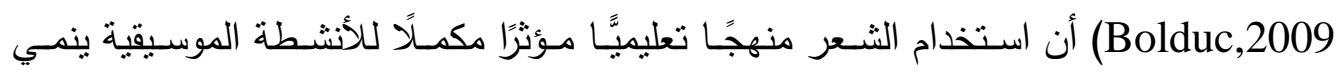

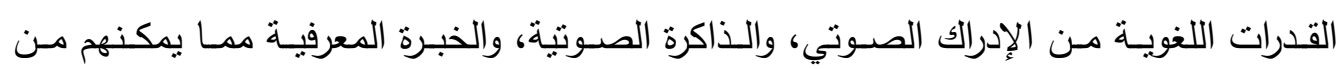

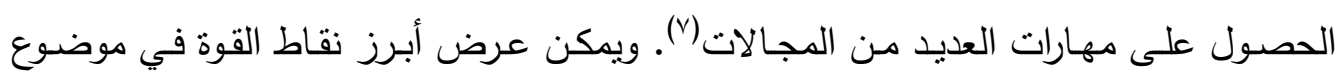
الدراسة على النحو التالي: 
- - أهميـة المرحلـة التـي توجـهـ لهـا النصـوص عينـة الدراسـة، ومــا لهـذه المرحلـة مـن

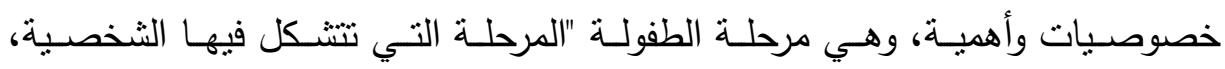
ويكتسب فيها الطفل مهاراته الأساسية من تعلم درامي، وذكاء اجتماعي" (^).

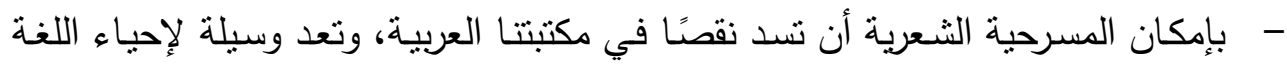

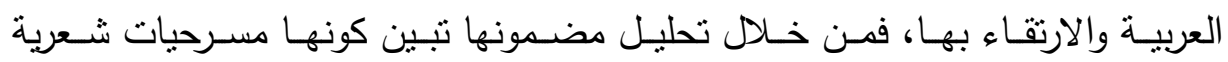
بالفصحى، قدمت للطفل المضـامين التربوية والحكايات التاريخية التي تدعو إلى القيم الإيجابية، ولا تتغير بتغير المكان والزمان.

\section{مصطلحات البحث:}

الخطاب الدرامي Dramatic discourse: تعرفه الباحثة إجرائيًا، بأنـه كتابـة فنيـة إبداعية

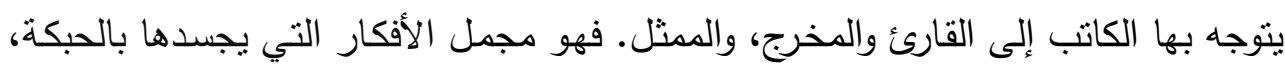

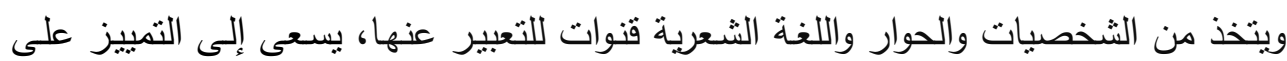
خشبة المسرح. المسرح الشعري للأطفال Poetic theater for children: يمكن تعريفه إجرائيًا بأنه: تسمية يقصد بها المسرحية المكتوبة شعرًا أو بلغة نثرية لها طابع شعري تتطوي على إيقاع وأوزان ومعانٍ مختارة وفقًا لقدرات المتلقي، وتستخدم اليوم للتمبيز بين المسرح المكتوب شعرًا

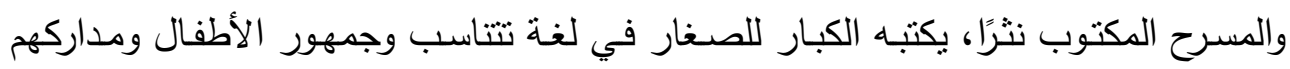

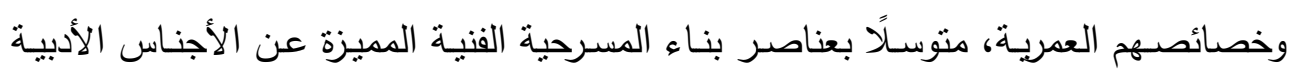

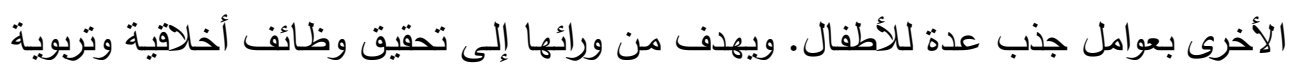
وفنية وجمالية.

الطفل: Child: يقصد بالطفل في هذه الدراسة، هو طفل المرحلة العمرية المتدة من مرحلة الطفولة المبكرة وحتى المراهقة.

بنية النص: Text structure: يمكن تعريف بنية النص إجرائيًا بأنها الجسم النصي الدرامي

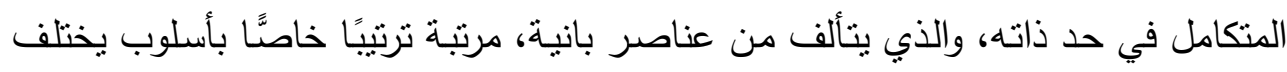
من كاتب لآخر، وأحيانًا من نص لآخر لدى الكاتب الواحد طبقًا لقواعد الكتابة الدرامية

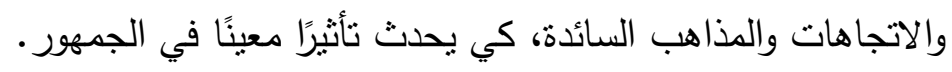


1- مجتمع البحث: الوقوف على طبيعة الخطاب الدرامي في المسرحية الثعرية للطفل وأثرها على بنية النص في مسرح أنس داود.

ץ - عيــة البحث: قامت الباحثة بقراءة وتحليل خمسـة نصوص مسرحية هي: مسرحية مامـا نشوى، وأربع مسرحيات شعرية تحت عنوان: حكايات السنونو (السنونو يصـادق أيمن، السنونو

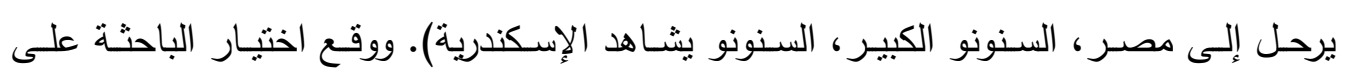
مسرحيتين لعرضـهم بالتحليل خطابًا وبنية، وهما (السنونو الكبير، السنونو يثـاهد الإسكندربة) اختيارًا متعددًا معتمدة في ذلك على:

- أن العينات ممثلة لمشكلة البحث وأهدافه وأهميته، ومن ثم يمكن تعميم نتائج البحث. - إمكانيـة رصــ الخطابـات الدراميـة للمسـرحية الثـعرية في هـذه النصـوص رصـدًا واضــًا وموضوعيًّا، وأسلوب البنية الدرامية لديه، إضافة إلى أنه من خلال قراءة وتحليل نصوص داود يمكن تصنيف مسرحياته تحت لواعين أساسيين هما: القومي والتربوي؛ مثلت مسرحية "السنونو

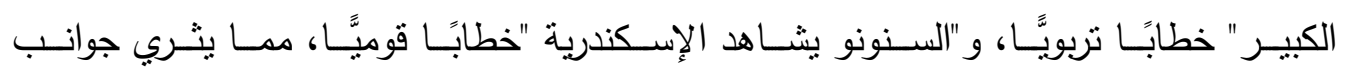
البحث ويعززه.

r- أداة البحث: اعتمدت الباحثة في تحليلها للعينات على ما أسفر عنه الإطار النظري بشكل عام، وعلى قراءة النصوص قراءة نقدية فاحصة.

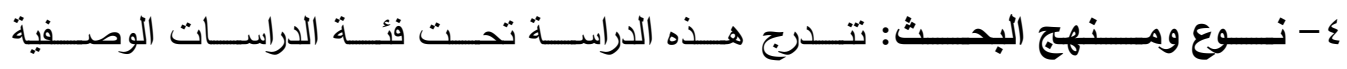
(Description studies) للاراسات الوصفية" حيث يولي الاهنمام لدراسة الأبنية الفنية؛ أي: الأسس الأدبية التي تتطور على مر العصور ، دون أن يتغير جوهرها الفني الذي كان وما زال العامل الأساسي الذي يمكننا من تذوق الفن ماضيه وحاضره"(9). 
أولاً: المسرح الثـعري للطفل: لم يبدأ المسرح شعرًا فقط، ولكن المسرحية في العصر الحديث

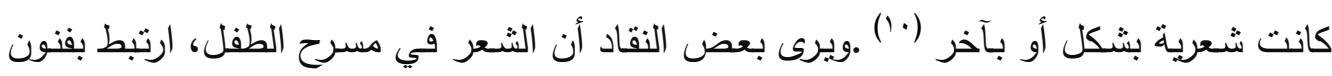

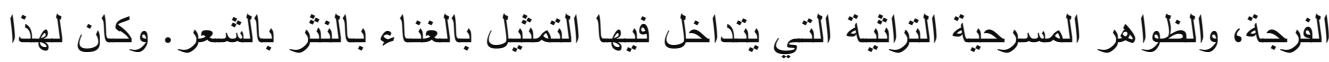

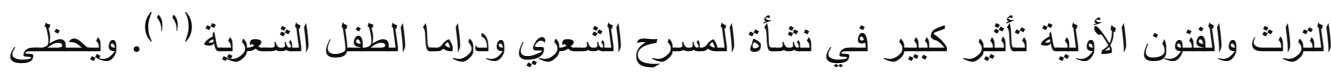

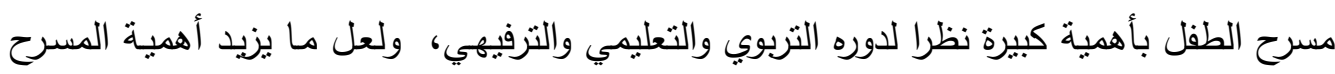

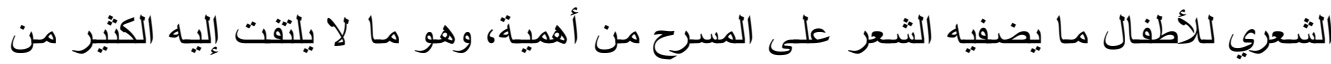

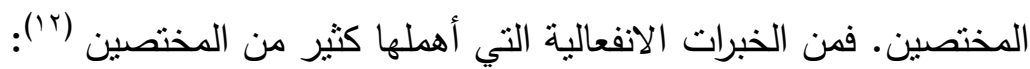
• ميل الطفل إلى الثعر القصصي الذي يأتي على ألسنة الحيوانات والجمادات. الميل إلى الثعر الغنائي المسرحي بطريقة إيقاعية حركية. • الميل إلى التراث الثعبي في ثقافة الطفل ومعرفة أسراره. الجمع بين الجانب المعرفي والجمالي والوجداني والعاطفي.

وهذه النقاط تظهر أهمية وفعالية المسرح الثعري الذي يجتمع فيه أكثر من عنصر يحتوي

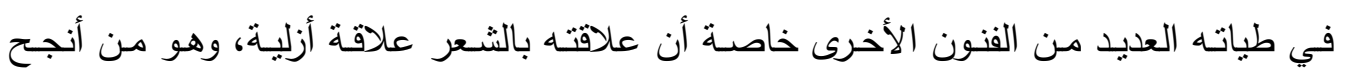

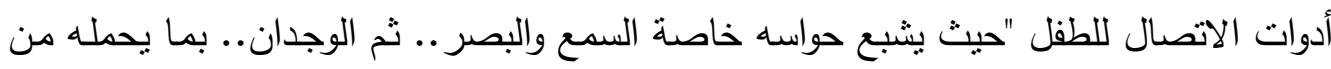
قيم ومتعـة وجمـال، وإن تعانق الدراما والثـعر في توازن معقول يمكن أن يخلقا وجدانًا ناميًا

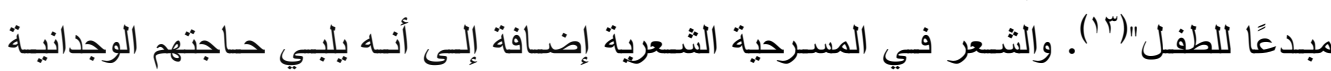

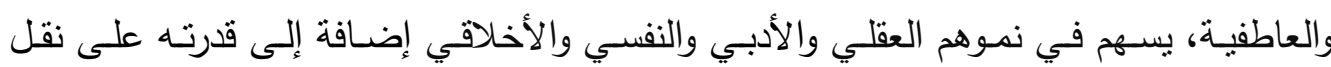

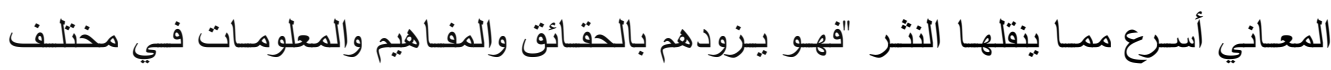

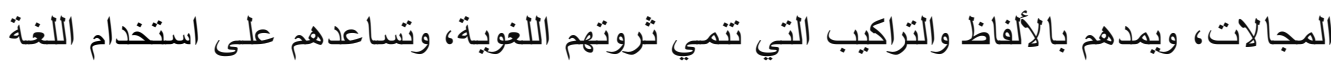

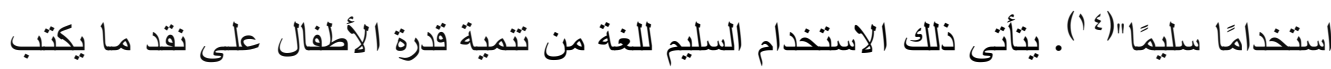

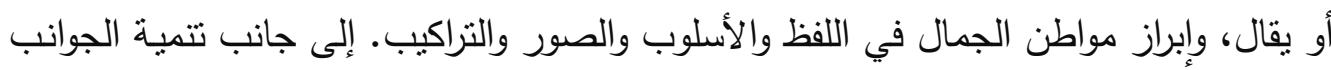
الوجدانية والأحاسيس، وغرس القيم التربوية والميول الأدبية والقرائية والحاجات النفسية المختلفة.

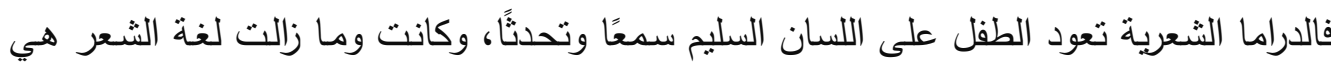

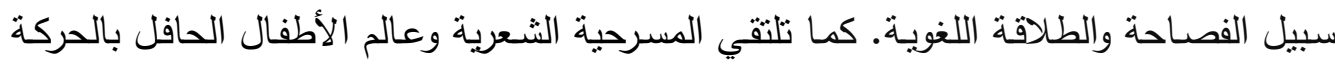
والصسورة والإيقاع والنغم، مستوعبة مراحل مختلفة من التطور الاجتماعي واللغوب، فمثنًا في

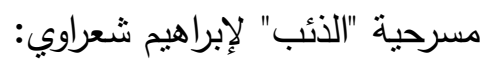




$$
\begin{aligned}
& \text { جوقة الضفادع: صبرًا صبرًا يا أرنب الأنب غدًا يتأدب }
\end{aligned}
$$

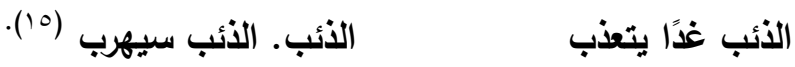

تتنمي لغويًّا وخطابيًّا إلى طور نمائي يختلف عن ذلك الذي تقدم له هذه المسرحية مثلًا:

$$
\begin{aligned}
& \text { الجندي: تقديرًا مني للجها }
\end{aligned}
$$

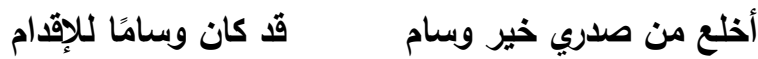

$$
\begin{aligned}
& \text { ووسام مجاهدة ووفاء }
\end{aligned}
$$

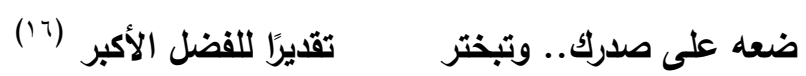

فالنص المسرحي يقدم للطفل نسقًا خطابيًّا بعيدًا عن المباشرة، يتسلل إلى وجدان الطفل

مفعمًا بنغمات اللحن الموسيقي الرقيق متوافقا والخصائص النمائية.

سمات المسرح الثعري للأطفال: يتسم المسرح الثعري للأطفال بمجموعة من السمات أوجزت

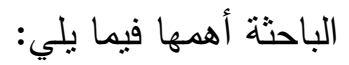

هُالمزج بين الثـعري واللارامي: جمالية ذللك الفن الأدبي وتميزه في مزجها بين ما هو درامي

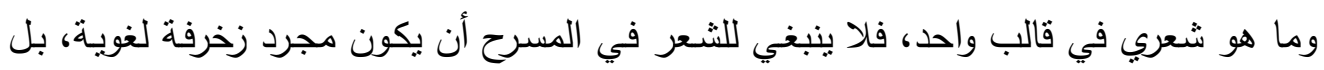
يتعين عليه أن يبرر نفسه دراميًّا؛ بحيث يدرك المتلقي وقتنئذ أن الثعر هنا هو فئي أداة التعبير. •• وحدة الروئية: إن الهدف الأساسي من النص الأدبي عامـة والمسرح الثـعري خاصـة هو

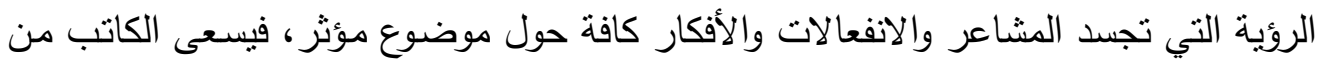

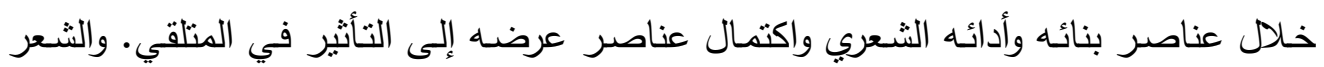
في المسرح يعمق هذا التأثير ؛ لما يضفيه على الحوار والصراع بين الثخصيات من جماليات شأنها جذب الطفل المتلقي للاستمتاع بمتابعتها دون ملل. والروئيـة هنـا في مسـرح الأطفال الثعري لابد أن تكون محددة واضحة غير منشـعبة، كما يتعين على الكاتب أن يحسن تقديم

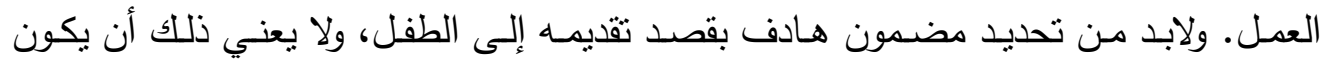
مضمونًا جافًً، ولكن في إطار من المتعة الفنية والجمالية، فمن خلال العناصر الفنية والجمالية

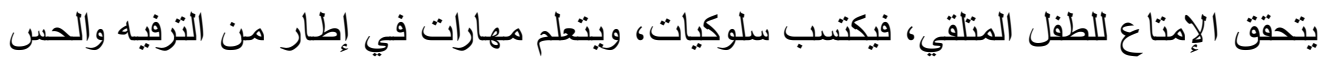

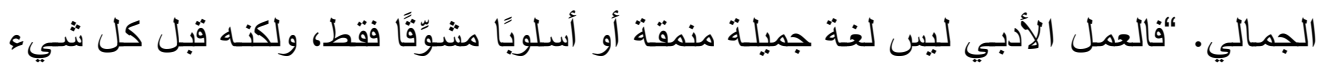

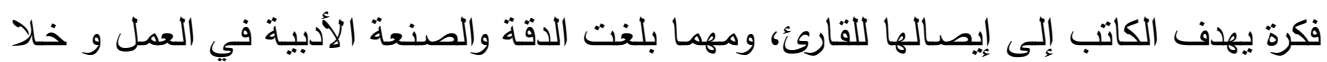

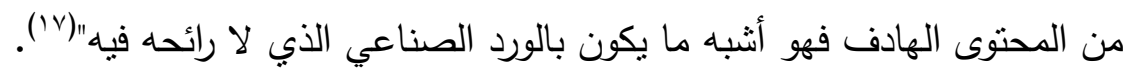


بـاللغـة والخيـال: اللغـة عنصر أساسي في أي عمل درامي، واللغـة في المسرحية الثعرية، تضطلع بالوظائف نفسها التي تقوم بها في المسرحية النتريـة، إلا أنها هنـا تتميز بالإيجـاز والتكثيف، وأنها ليست هدفًا في حد ذاتها، بالإضافة إلى أن اللغة الثعرية هنا محكومة بالفئة التي تقدم لها، وما يتعين على ذلك من شروط لابد من توافرها ومراعاتها. وتذكر كاريت.س.

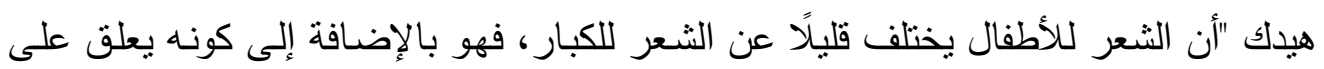
الحياة بمستوى يحمل معنى وهدفًا للأطفال، فإن خاصيته تكمن في لغته الثـعرية، ومحتواه

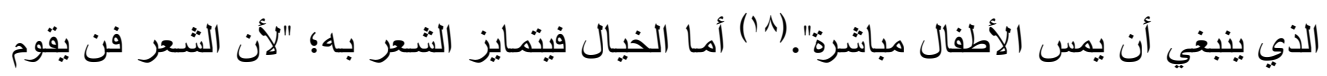

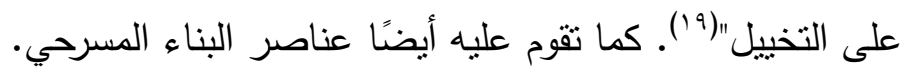

بـالاهتمام بالمتلقي والتعبير عن الخبرات الانفعالية: المسرحية الثعرية لا تعتمد على تطور الحدث الدرامي، أو تقديم الصراع فقط في إثارة المتلقي، "بل تعتمد على اللغة الثعرية الكثيفة

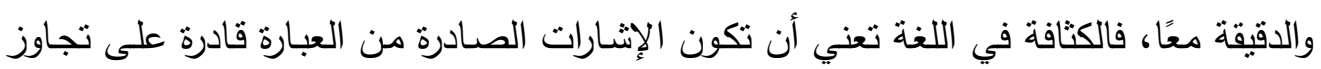
المعنى الحرفي الظاهر إلى معنى رمزي يساعد على تشغيل ذهن المتلقي ومحاولة دفعه لإنتاج

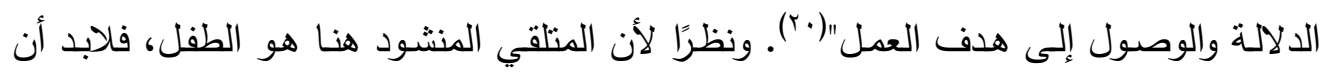
تتوافق اللغة الثعرية والمضمون وفئته العمرية، فالمتلقي هو حجر الأساس الذي من أجله يتم إنجاز العملية الإبداعية ككل. بعبارة أخرى أن تتناسب لغة الثناعر وقدرة المنلقين، وتحتفظ في هني الوقت ذاته بدراميتها وجزالتها وصورها.

ثرالضوابط البلاغية: وإذا كان "وظيفة فنون البلاغة في الدراما الثعرية هي التقاط جماليات مؤثرة من أحد عناصر الفن الدرامي؛ لكي تغذي فكر المتلقي جماليتها"(r). فإنها في مسرح الطفل يتعين بها أيضًا إلى الجانب الجمالي أن تتسم بالوضوح والبساطة التي لا تؤدي إلى أب لغي لبس أو غموض في تلقي المضمون.

• ثعدد الأصوات: الثشاعر المسرحي يتعين عليه أن يجرد عمله من أفكاره الخاصـة، ولا يزج بها في ثنايـا شعره، بـل يترك الثخصيات تتحدث عن نفسـها، وكذلك الأثتياء والأحداث.

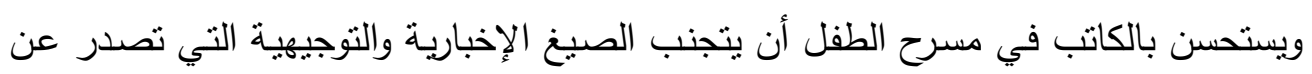
صوته هو ، حتى لا ينصرف الطفل المتلقي عما يقدم إليه. 
ثانيًا: تطور المسرحية الثسرية للطفل في مصر : إن محاولة التقسيم بين مراحل المسرحية الثعرية وتطورها ليست صارمة، وإنما هي محاولة من أجل البحث والدراسة، كما أنه قد يوجد

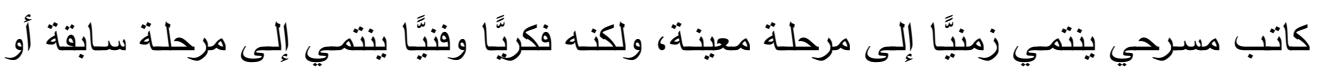

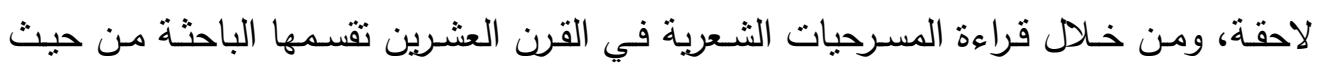

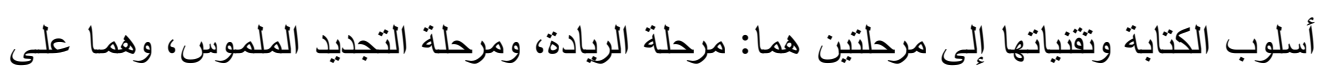
النحو النالي:

• المسرحية الثعرية في النصف الأول من القرن العشرين/ مرحلة الريادة والإرهاصات الأولى: وهي تشكل مرحلـة البدايات لمسرح الطفل الثـعري، وأول من كتب ذلك اللون من المسرحيات للأطفال هو محمد الهراوي. كما برزت بعد ذلك كتابات محمود غنيم، ومحمد يوسف المحجوب الذي تعده الباحثة نهاية هذه المرحلة، ويقع جزء من كتاباته في النصف الأول من القرن العشرين وهي سلسلة المسرحيات الدينية، والجزء الآخر في النصف الثاني من القرن العشرين وهي سلسلة مسرحيات المعركة، ولا تعدها الباحثة بدايـة لمرحلـة جديدة

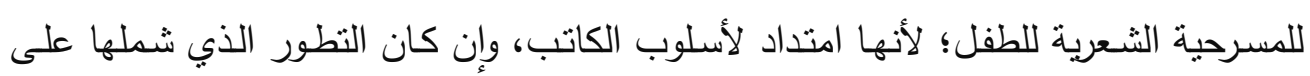
مسنوى المضمون كاستجابة لمتغيرات العصر والأحداث السياسية.

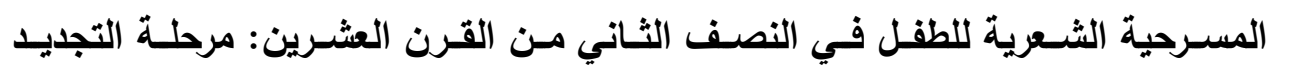

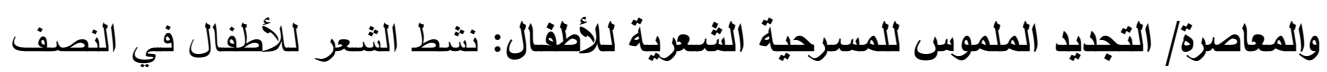
الثناني من القرن العشرين، وظهرت إبداعات أدبية لثعراء في أنحاء الوطن العربي، موجهة للأطفال تتوافق والخصائص النفسية والمرحلة العمرية المقدمة لها، وجاءت تجارب هؤلاء الرواد تحمل في طياتها من الجدة والإجادة الفنية مـا يشكل مادة ثريـة لأدب الأطفال الثتعري، وإذا كانت القصيدة هي أكثر الأشكال الأدبية التي استأثرت بالثعر تبعتها القصة، فإنه على صعيد المسرح الثـعري وجدت تجارب غنيـة بـالقيم الفنيـة والتتربــة التي تنـتحق الدراسـة والمتابعـة. تتميز هذه الفترة بانفتاح اجتماعي وفكري وتمايزت الفنون والآداب. ومن أبرز ملامح هذه الفترة

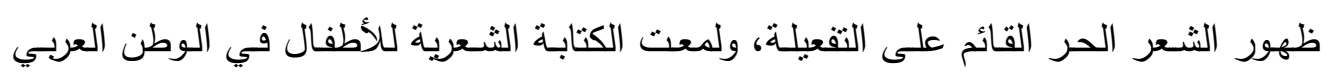
على يد العديد من الثعراء، وانعكس التأثنر -على قدر كبير - في المسرح الثـعري للأطفال. 
وأنتجت مسرحيات في النصف الثانى من القرن العشرين ذات ثقنيات جديدة، هدفًا ومضمونًا ومعالجة وأسلوبا و نأليفا، ولذلك فهي تخرج من عباءة المرحلة الأولى وأصولها التقليدية، ومن هذه التجارب الثرية مسرح أنس داود.

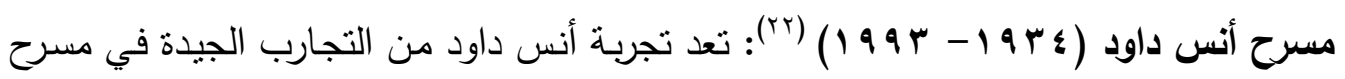
الأطفال شكلاً ومضمونًا. إلى جانب إسـهاماته في مجـال المسرح الثـعري للكبار، من أهم العوامل التي أسهمت في تتكيل أعمال داود المسرحية "ثقافته الدرعمية" الأصيلة، ثم ما هيأته له قراءاته المستمرة في الآداب الحديثة، وأسفاره ومراسه الطويل بالشعر والنقد والدراسات الأدبية، كل ذلك أسلحة وأدوات يجيد استغلالها من يملكها ويعرف قدرها"(r). وكان الثعر والثعراء دائمًا محل اهتمامه، كما أن الثعر كان وسيلته التعبيرية حينما انتقل من مرحلة الغنائية إلى الدرامية، وتذكر إخلاص فخري أن من أهم العوامل التي دفعت الكاتب إلى التوجه لكتابـة المسرحيات الثعرية بعد الكم الكبير من الدواوين والقصائد ما يلي (عَب): - - - أن الثكل الأول البسيط المتمثل في القصيدة، لم يعد كافيًا للثـاعر لحمل أفكاره وثقافته المتتوعة، وحاجاته المتطورة، لذا كان اللجوء لقالب أدبي جديد.

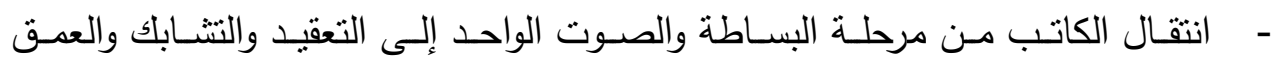
والصراع المتوافر في المسرحية وعناصرها. - أن الكاتب انتقل مـن مرحلـة الذاتيـة إلىى الجماعيـة الإنسـانية، وأصبـح أكثر اهتمامًا بالمجتمع ومتطلبات الواقع. - الانفتاح الذهني والأبعاد الجديدة في شعره التي تتجلي في تحوله من الصوت الواحد إلى الأصوات المتعددة، والمناجاة الذاتية إلى الحوار ، وتبادل الآراء.

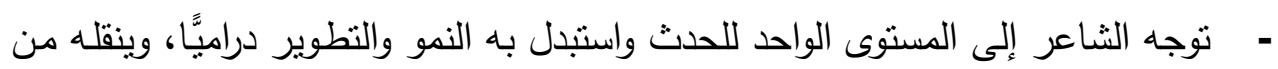
مرحلة لمرحلة أخرى، مع عدد من زوايا تجمم الصورة وتوضحها. فقد قدم في مطلع

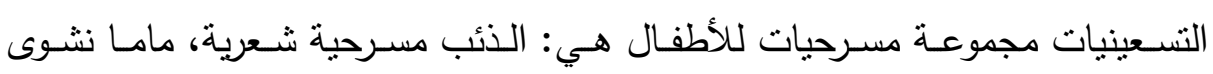

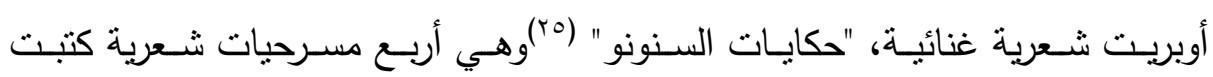




\section{ثانيًا الإطار التطبيقي: ألإن}

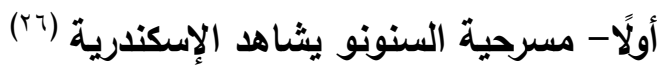

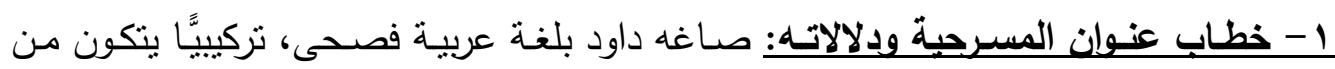

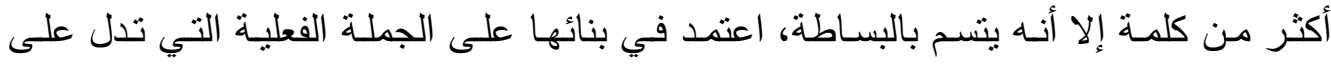

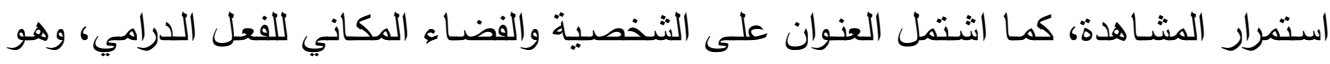
الإسكندرية. ربط الكاتب عنوان المسرحية بالعنوان الخارجي للمجموعة حيث جعل الطائر محورًا

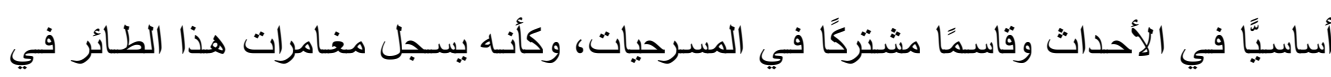

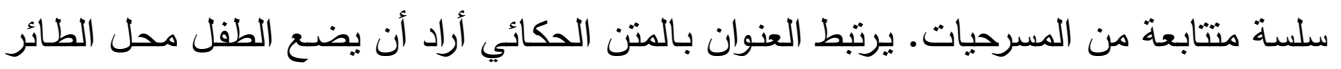

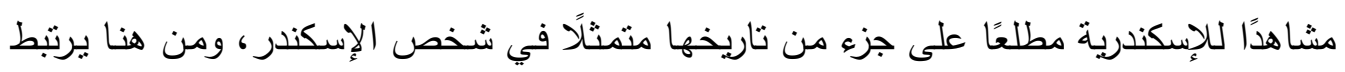

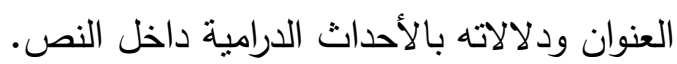

ب -خطسب الكاتب القيمي في المسرحية: يدور حول موضوع قومي، وهو التعريف بمدينة

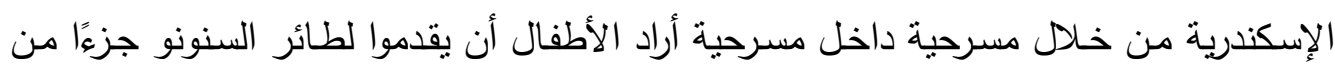

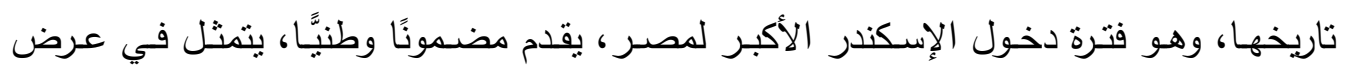

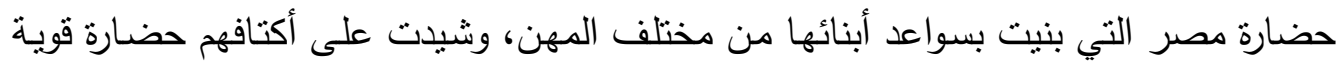

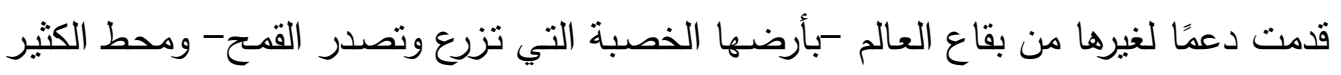

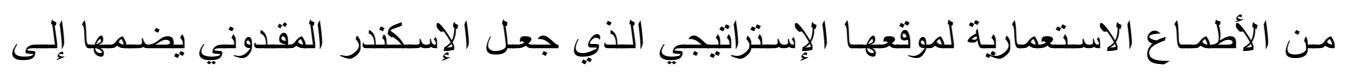
إمبراطوريته، ويؤسس بها مدينة الإسكندرية: الجوقة: إنتا شعب الحضارة

نملأ الانيا مهارة النفارة

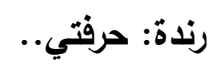

أن أمنح التريبة

خصبًا ونضارة

رغدة: وأنا النجار .. في كفي ونضارة

منشار، وفارة

الأم: وأنا فنان في المعمار ...

شيدت معابد للآلهة، المعان

أخضعت لإزميلي الجبار

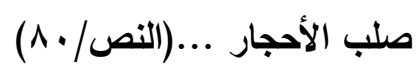


وفى نهايـة النص يتعرض لقيم أخلاقية ترتبط بالدين؛ نتيجة سعة تقافة داود، استغل مـا عرف عن تتويج الإسكندر بابن آمون كبير الآلهة حينما دخل مصر ، إلى التأكيد على وحدانية

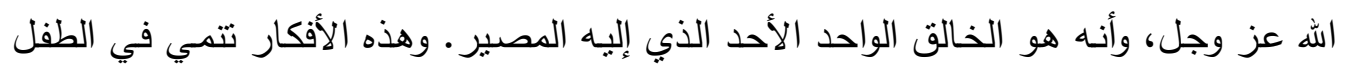

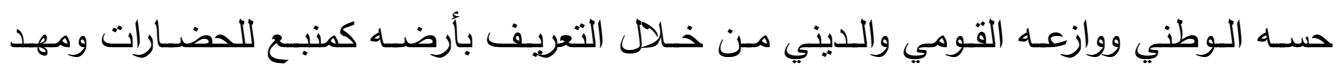
للايانات ومصدر للخير والعطاء.

ب- لغة الخطاب وإيقاعه: (المستوى اللغوي، الإيقاعي، والتصويري) لغة عربية فصحى بسيرة تخاطب مرحلـة الطفولـة المتوسطة، جاءت ألفاظها في مجملهـا ثلاثيـة سـريعة الإيقاع تـؤدي

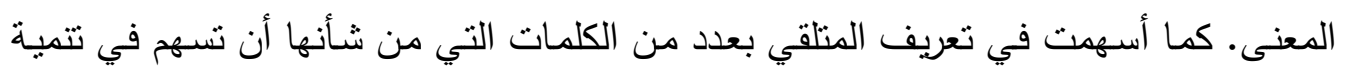
الحصيلة اللغويـة، كما اثتملت على تعريف الطفل بأدوات ترتبط بـالمهن المختلفة (كالمنشار

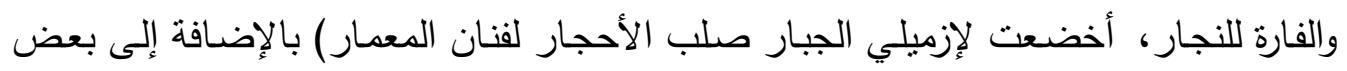

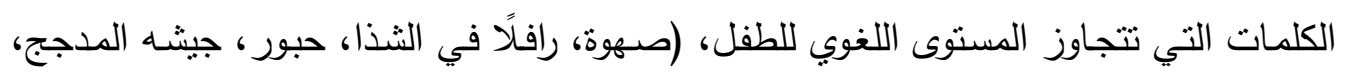

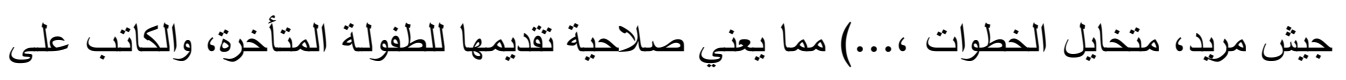
وعي بذلك فيذكر داود "ففي تجاربي الإبداعية في شعر الأطفال وفي مسرح الأطفال أجد نفسي لفي

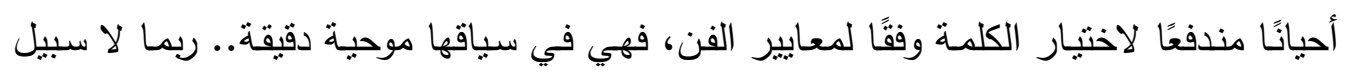

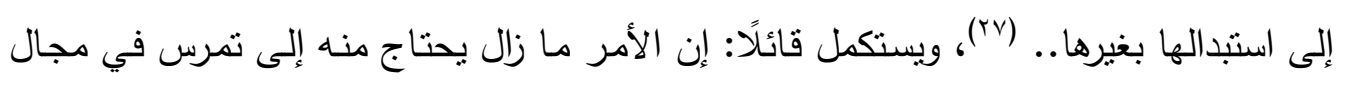
الكتابة للأطفال.

الـلالات الإيقاعيـة للخطاب: بنى النص على نوافر أكثر من وسيلة لتحقيق الإيقاع الداخلي

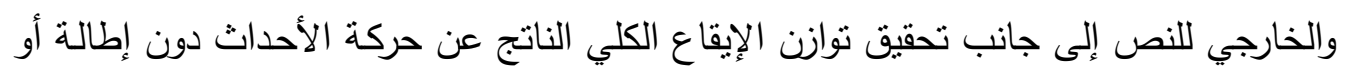

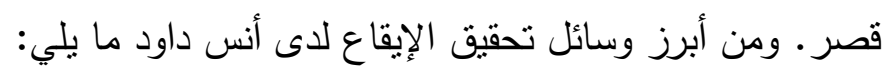

الوزن والقافية: لا يخلو أي نص مسرحي من الأوزان والقوافي، وبناء داود للنص على الثعر

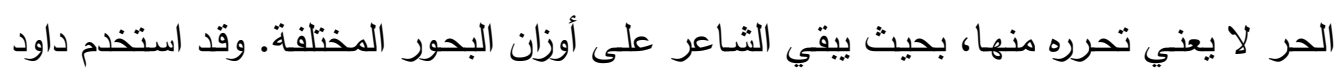

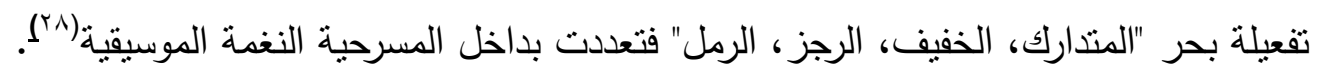
التكرار: له أكثر من شكل داخل النص، من أبسط مظاهره تكرار الكلمة، وهو الأكثر شيوعًا في بنائه، ثم الجملة، ثم تكرار المقاطع الحوارية وربطها بالثخصيات "فكل تكرار يحمل في ثناياه دلالات نفسية وانفعاليـة مختلفة تفرضـها طبيعة السياق الثـعري، ولو لم يكن ذلك لكان تكرار الجملة من الأثياء التي لا تؤدي إلى معنى أو وظيفة في بناء الثُعر ؛ لأن التكرار إحد الأدوات 
الجمالية التي تسـاعد الثـاعر على تشكيل موقفه وتصـوره"(9). فاستهل النص بتكرار الكلمـة،

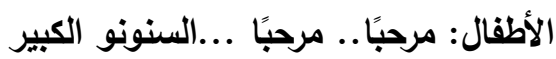

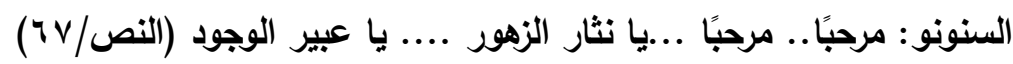

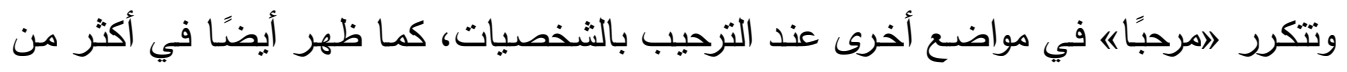
موقع داخل النص (انظروا.. انظروا..، اطمئن ...اطمئن، مصر ...مصر ، الجمال الرفيع.. الجمال البديع، واعجبا.. واعجبا..) وجميعها تمنح الحوار موسيقى تطرب لها الآذان إضافة إلى وظائفها الدلالية في تأكيد المعنى. كما اعتمد على تكرار المقاطع الحوارية لما لها من أهمية في تدعيم الفكرة الأساسية: - الفية

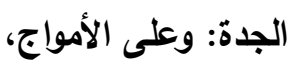
أجريت سفينًا وسفينا كالقلاع

تحمل القمح إلى العالم (النص/V9) كرر الكاتب المقطع نفسه على لسان الجدة(النص/• •) وذللك من أجل التأكيد على المضمون الذي يريده، فهو يبرز للطفل أهمية مصر وحضارتها. اللالالات التصويريةة: إلى جانب المحسنات البديعية استتد الكاتب إلى عدد من الصور الفنية

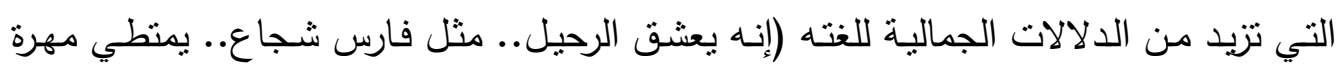
النيل..)، (أنتم الأنسام في السحر ، وأنتم الثموس في النهار ، في الليالى أنتم النجوم والقمر ، قطعة من البهاء والسرور) وهي بسيطة نتوافق ومعارف الطفل، ولا يصعب عليه فهمها. الأسـلوب: يتسم الأسلوب بـالتركيز حول الأفكار التي يتعرض لها ودورهـا في تدفق الحدث

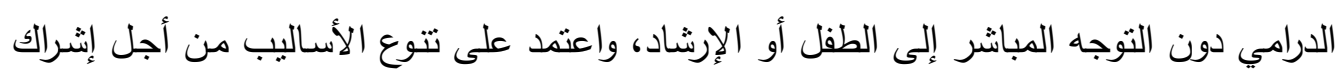

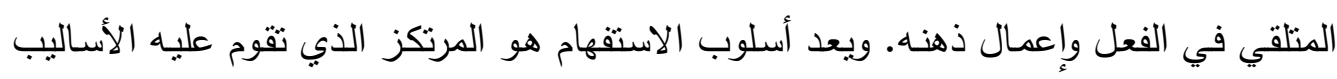

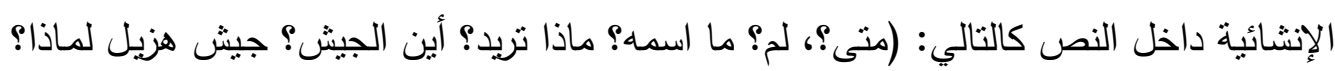
من أنت؟) فهو استقهام (مباشر) في دلالة نقريرية لا تحتاج إلى نفي أو إثبات.

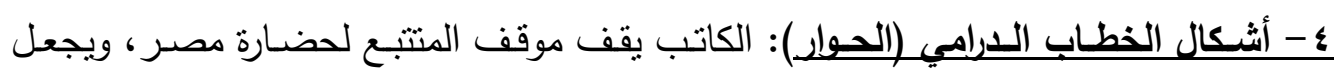
الأطفال والطائر مشاهدين لمدينة الإسكندرية بسفنها وشواطئها وعراقة تاريخها. فجاء استعمال الألفاظ يتوافق وقاموس الطفل، بأسلوب الجمل القصبرة ذات الدلالات والمعاني التي يفههها،

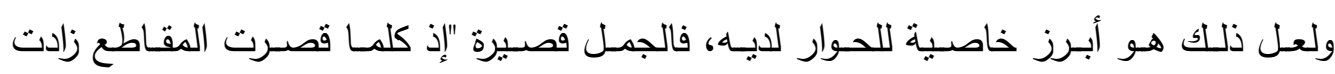


العلاقات النصية التعبيرية تماسكًا وعمقًا ودلالية، وأصبح كل شيء موضوعًا بدقة وقصدية لا

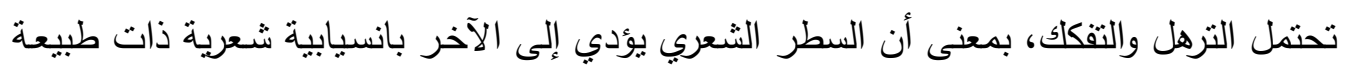
درامية"(·r). ويكثف الحول والفكار عن الفكرة بوضوح كان التالي:

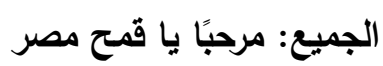
مرحبًا قوت العباد مرحبًا أفضال مصر فر العباد غامرات للبلاد اسلمي يا روح مصر وا هنئي في كل ناد

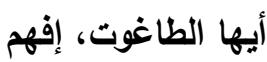
مصر تبني.. أنت تهدم مصر تزرع.. أنت تقلع مصر تكتب.. أنت تثطب

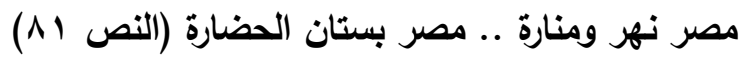

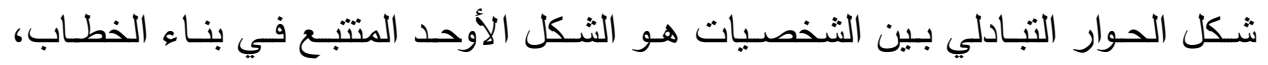
والكاتب لجأ في بعض أجزائه إلى تقطيع الجمل لنتارك في أدائها أكثر من شخصبة: رغدة: حثد عتبا نوال: جيش مريا

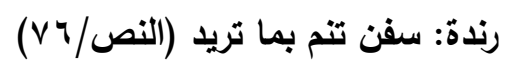
كما أن الحوار كثف عن طبيعة الثخصيات المشاركة في الموقف والتعريف بها كما في لني شخصية الإسكندر الذي تقدم الثخصيات الأخرى وصفًا لله إلى جانب تعريف الثخصية عن نفسها، وهو بذللك يسهم في تحقيق نمو الأحداث، بما سيترتب على أقوالها من أفعال: الإسكندر: أبتغي أن أوحد البلاد، أبوان أن أوحد البشر أمنح العالم الكبير البير حلمه الرائع النضير العالم الكير

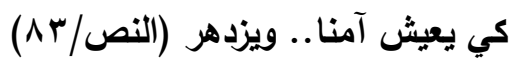


التتـاص: وتتوع التتاص لدى الكاتب بين التتاص الديني إلى التاريخي وصولًا إلى التتاص الثعبي، وسوف نتتاول أبرز مظاهر ذلك التضمين على مستوى الخطاب.

التتاص الديني: اقتصر الاقتباس الديني على القرآن الكريم، وذلك من خلد استحضـار الآيات

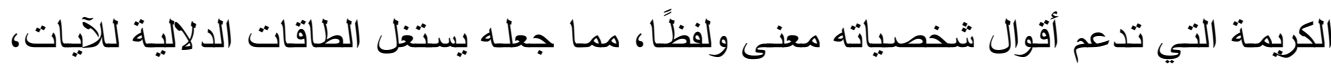

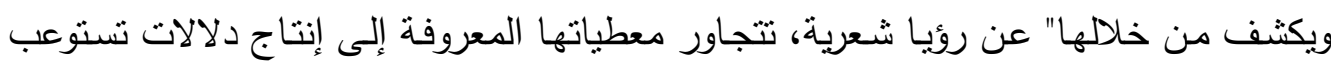

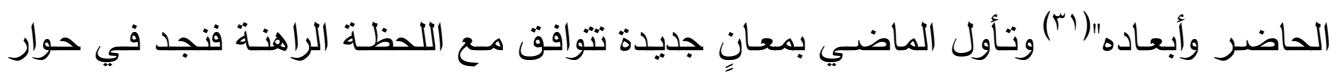

$$
\begin{aligned}
& \text { الجوقة: واحد أحل ... فرد صمد } \\
& \text { الجدة: له العزة والملكوت } \\
& \text { وله السطوة والجبروت } \\
& \text { وإليه يعود الإنسان } \\
& \text { ليسأل عما يفعل بعل الئان }
\end{aligned}
$$

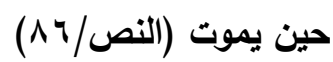

فمن المعروف تاريخيًّا أن الإسكندر في رحلته إلى مصر قام برحلة إلى معبد آمون حيث

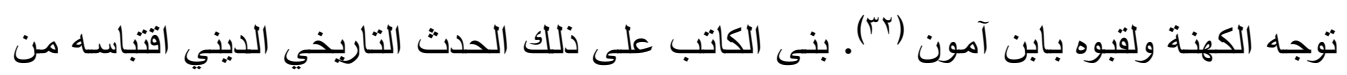

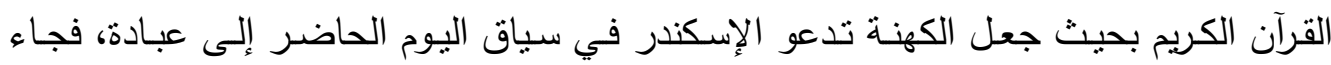

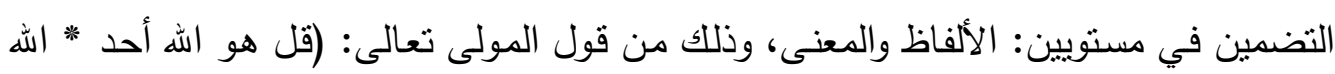

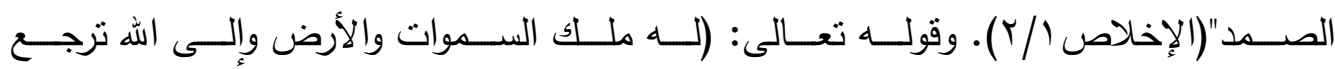
الأمور"(الحديد/ه)، وقوله: "من كان يريد العزة فلله العزة جميعا"(فاطر / • ( )، وقوله: "فسبحان

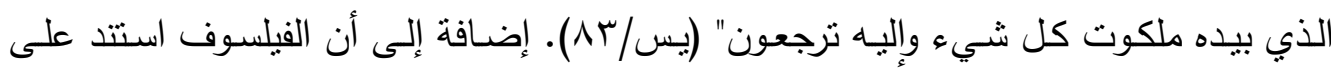

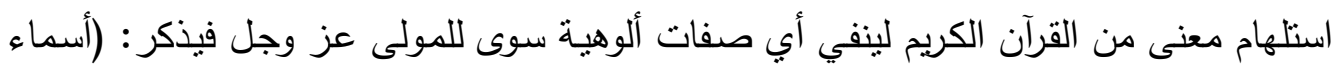

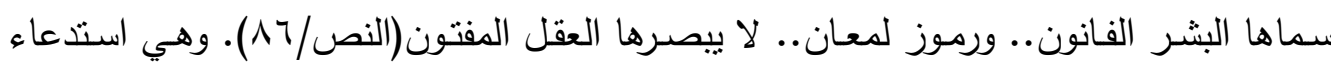

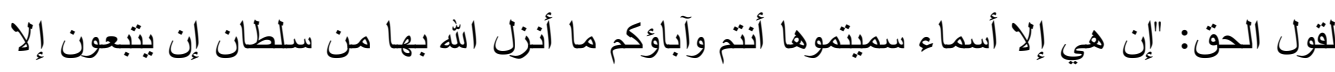

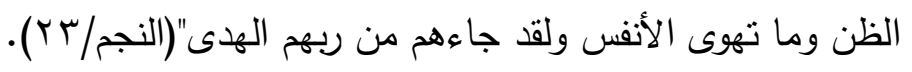

التنـاص الثـعبي: تتـاص الأمثال الثـعبية كنوع "من أنواع الأدب يمتاز بإيجاز اللفظ وحسن

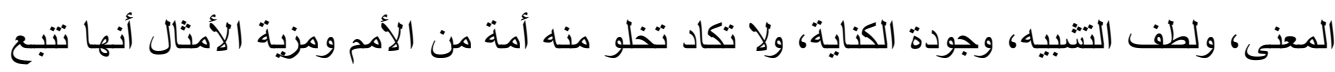

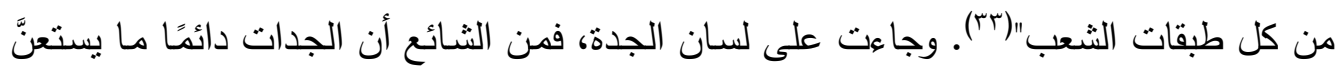


في حوارهنَّ بالأمثال الثُبية. وجاء تضمين المتل مناسبًا على مستوى الموقف والثخصية بلغة عربية فصحى فتنكر الجدة: "لن يبصر الأصحاب من يقابل الأحباب".

التنـاص التـاريخي: استدعيت الثخصيات التاريخيـة وشـاركت في الحدث؛ ذلك لأن استدعاء أحداث وشخصبات من التاريخ لله دلالات، من شأنها الكشف عن واقع تجاربها التي عاثشها بعضهم، والتذكير بماض عربق وقادة أبطال. وجاء ذللك الاستحضسار على مستوى الثخصية

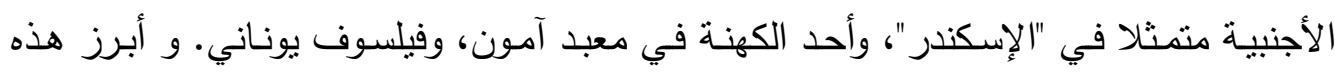
الثخصيات هي الإسكندر في رباط مع الحدث التاريخي وهو دخوله إلى مصر ـ لكنه أضفى الإنى

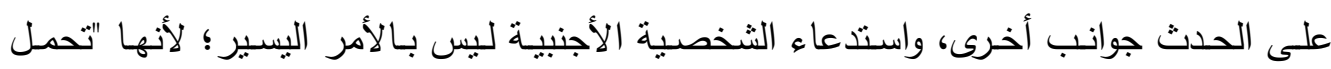

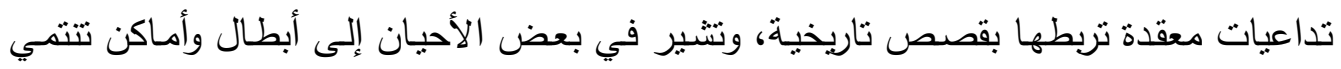

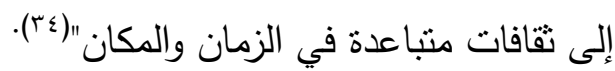
الجدة: كان قائد شهير يقود جيشه المدجج الغفير يقتحم البلدان ويقهر الفرسان تجثو على أعتابه

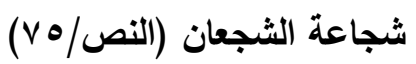

هـ خطـاب الإرشـادات المسـرحية: تشكل إرشـادات الثخصية أهميـة في مسرح داود، تليها إرشادات الفضاء الدرامي، وعناصر التصميم، ويمكن تتبعها داخل النص كالتالي: 1- وصف الثخصية: لم يرد وصف دقيق للشخصيات، معتمدًا على أبعاد الثخصيات لاى

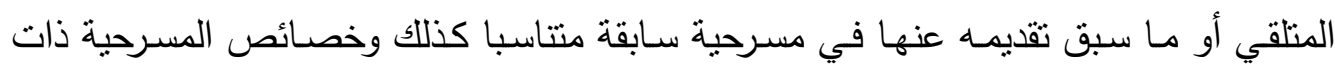
الفصل الواحد. ونجد في النص توجيهات قليلة حول الحركة والأداء الجسماني كالتالي: (الجميع

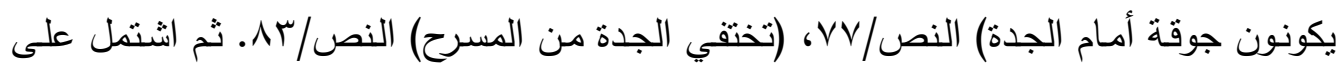

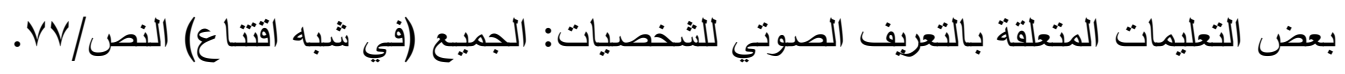
الإسكندر (في تعاظم) النص/r/ اليجسد من خلالها انفعالات الثخصية وحالتها.

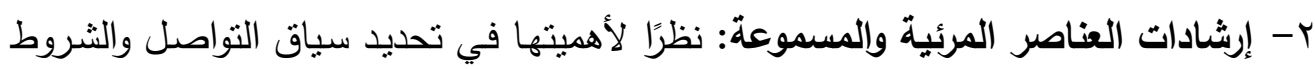

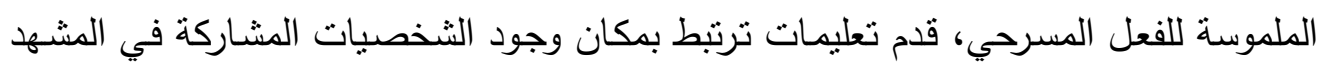
"حديقة في مدينة الإسكندرية.. الأطفال أيمن، رنده، نوال، يضاف إليهم في هذان وجناد المشهد: رغدة، 
الأم، الجدة، السنونو الكبير يحط على غصن شجرة"(النص/T/T). ثم قدم توجيهات تتعلق بإنهاء موقف درامي وبناء موقف درامي لاحق عن طريق الإضـاءة كوسيلة لتغيير المشاهد،

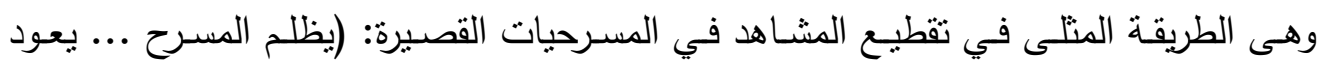
الضوء مظلالا. الأطفال والجدة والأم في ثياب تاريخية.. أيمن غائب عن المسرح؛ لأنه سيعود

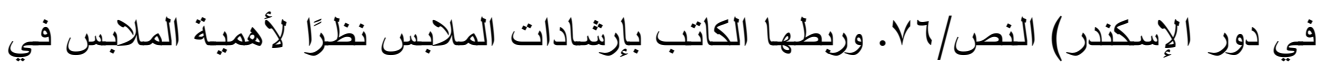

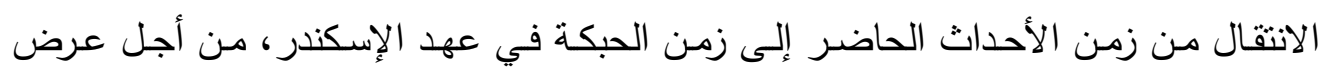
وتدعيم الفكرة.

ج-خطاب الثخصسيات في المسرحية: الثخصيات في النص قليلة تعتهد على عدد من

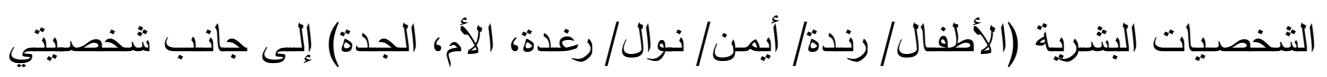

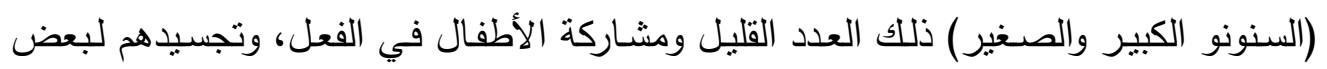
الأدوار جميعها تتوافق ومرحلة الطفولة المتوسطة.

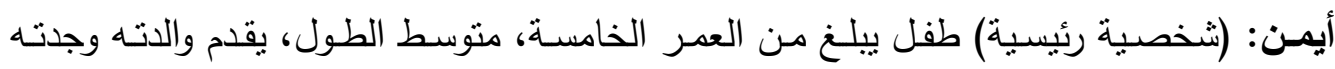

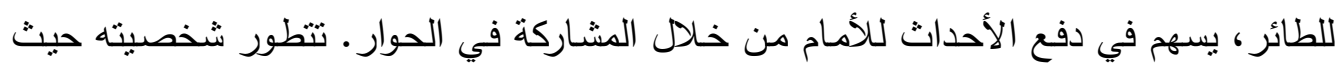

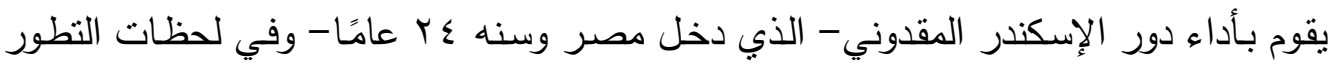
الدرامي، يختفي فترة ويعود متتكرًا في زي تاريخي حيث "يستحضر الثخصية التاريخية بصفاتها وأثرها في الذاكرة، فهو يحيل قارئه إلى إعادة إحياء الأثر وتمكينه من تفصيل أسبابه ونتائجه

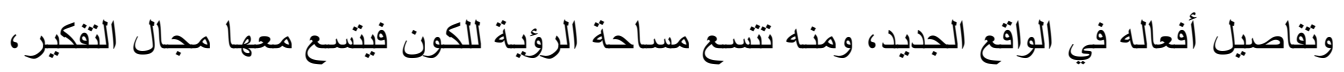

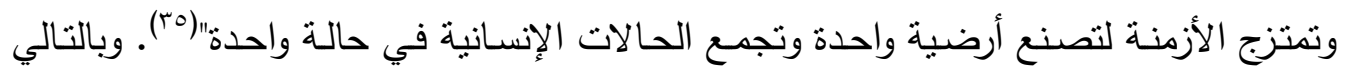

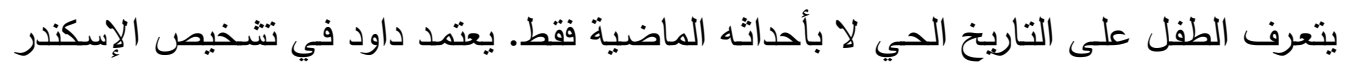
عن طريق الكلام فيذكر عن نفسه: الإسكندر: لا... وعزة الحياة جئت أبتني الوجود

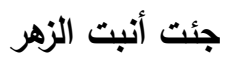
أبعث الغد الجميل في البوادي، في الحضر الجميل جئت أرفع القيود جئت أنقذ البشر (النص/ الفودم) 
الجدة: شخصية رئيسية، جدة الأطفال، في العقد السابع من عمرها، تمتل صوت الحكمة والعقل في المسرحية، فمنها تصدر الأمثال والاقتباس من القرآن الكريم، وهي التي تعدي تعدد للأطفال أوجها

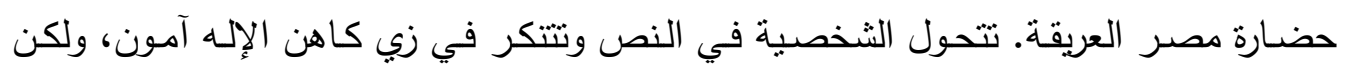
دعوتها للآلهة لا تتمثل في آمون ذاته، وإنما في التوحيد والإيمان.

الأم: شخصية ثانوية، هي أم الأطفال تسهم في الكثف عن جوانب الفعل مما يدفع بالحدث في

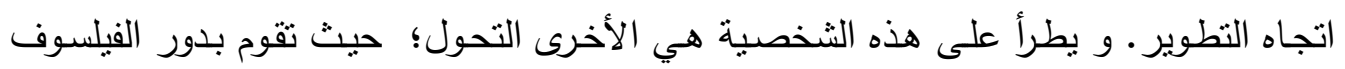
اليوناني الذي يقنع الإسكندر بأن الخالق واحد، وأنه لا وجود للآلهة اليونانية. السنونو الكبير/الصغير: (ثخصيات ثانويـة) - في هذا النص بالرغم من كونها محوريـة في

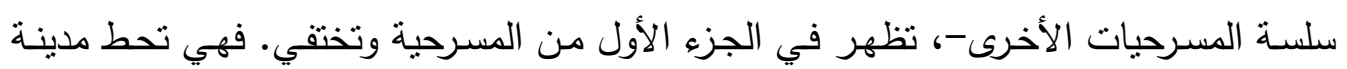
الإسكندرية يستغلها الكاتب كثقديمة درامية للانتقال إلى المستوى الثاني من الأحداث.

الأطفال (رغدة، رندة، نوال): شخصيات ثانوية تعلق على الأحداث وتسهم في بنائها، كما أنها

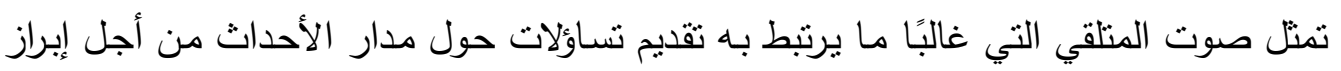
جوانب الحدث كافة.

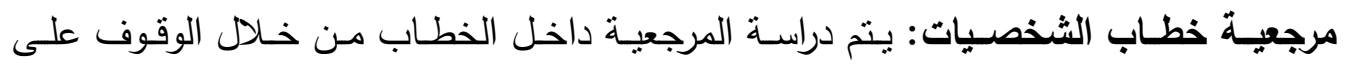
توظيف داود للضمائر الذاتية داخل الخطاب، وتحديد عناصر الفضاء دراء الدرامي.

الضمائر الأتية ودلالاتها داخل الخطاب الدرامي: الضمائر تمثل الثخصيات في أي خطاب

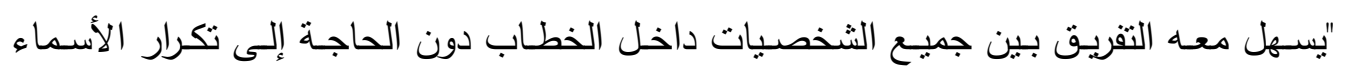

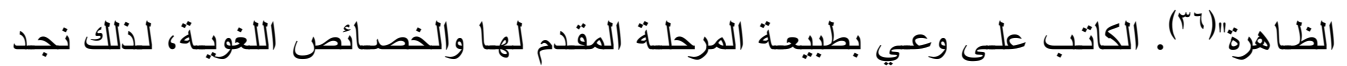
توظيفه للضمائر في النص واضحا - منكلم ومخاطب- المنفصلة منها والمتصلة: (هذه أمنا، هذه جدتي، هذه أختنا، أنت.. قائد جسور ، أنا هنا) ولكل من هذه الضمائر وطائر وظائف دلالية يكمل

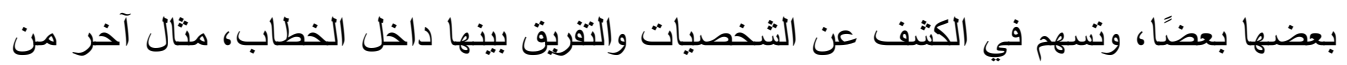
النص: بعis

السنونو معًا: عفوًا رفاقنا اللطاف نعتذر .. ونعتذر فأنتم الذين جملتم لنا الحياة حبيتم لنا هذي الصور وأنتم الأنسام في السحر (النص/VT) 
في هذا الخطاب استعمل الضمير المنفصل "أنتم"، والمتصل للمتكلم "نا" في الحيز الفعلي

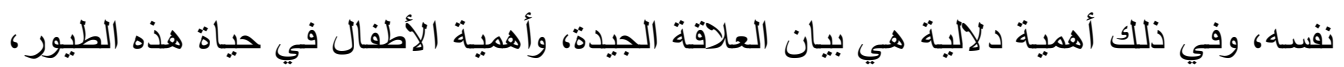

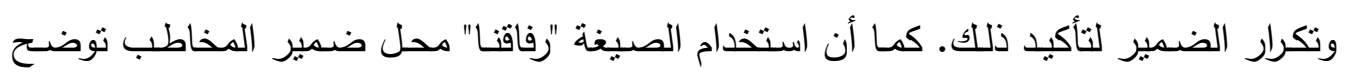
العلاقة الحميمية بين الثخصيات، وتضفي تتوعًا على بناء الجمل.

البيئة الزمنية: تدور الأحداث في النص على مستوبين زمنيين للأحداث الأول هو لقاء الأطفال

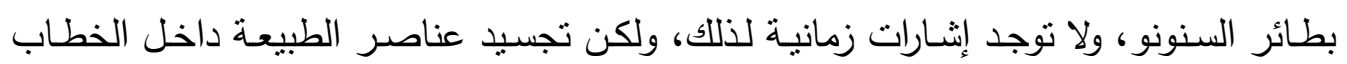
توحي بطبيعة الجو، مما يشير إلى أنها في جو ربيعي مناسب لطبيعة الطيور المهاجرة بحثًا

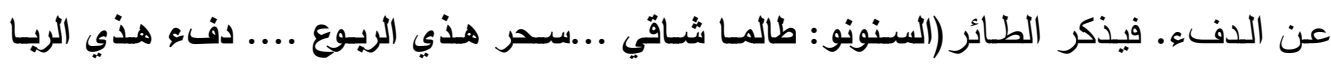

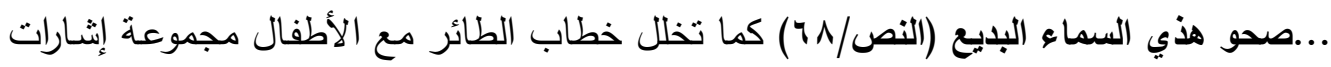
زمنية غير محددة لا تكثف عن طبيعة الزمان بالتحديد منها (السنونو الصغير : آن لي اليوم أن

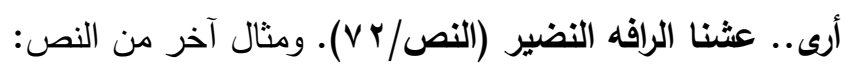

الصغير: لو كنت ها هنا

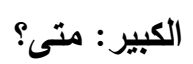

الصغير : بالأمس بينتا

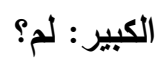

الصغير: مرت مواكب. بلا نظير.. تعيد رسم صورة.. من أقدم العصور .. يزهو بها التاريخ والأجيال والدهور

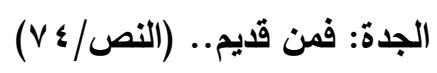

فهي بمثابة إثنارات للانتقال بالمنلقي من زمن الحدث إلى مستوى زمني آخر حيث تؤدي

الثخصيات أدوارًا تاريخية تستدعي ظهور الإسكندر وتجسيد جزء من فترة وجوده في مصر •

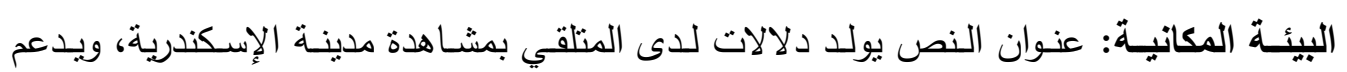

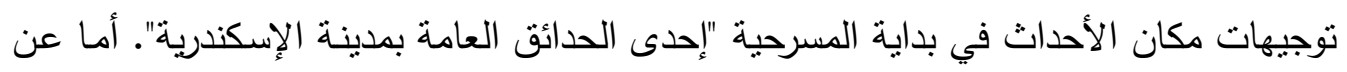
خطاب الثخصيات في تحديد السياق المكاني فتشير جميعها إلى أنها تدور في مصر بـانه على الإنى

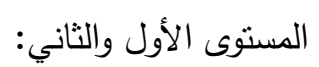
الكبير : نعشق الحقل والزهور الصغير : وتغتي لاى البكور الكبير: ونرى الثرق ضاحكا 


$$
\text { الكبير: ومن النيل نرتير أمان وفي حبور }
$$

الصغير : نفتدي الكوثر الطهور(النص/VY)

السنونو: حلوة مثل وردة ...مرحبًا بالجميع.. مصر أم الحياة ... مصر مهر الربيع (النص/VY) - V آلبات البنبة الدرامبة وأسلوب التأثر بالخطاب الدرامي:

أ- الحبكـة: المسرحية تتعرض لخطاب قومي مما انعكس على بنية الحدث، حيث أصبحت أجزاؤه منفصلة، ونتيجة لعرض الأحداث منفصلة حاول الكاتب جعل الثخصيات هي المحركة

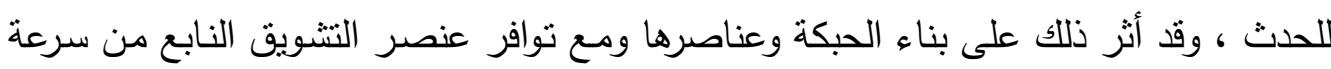

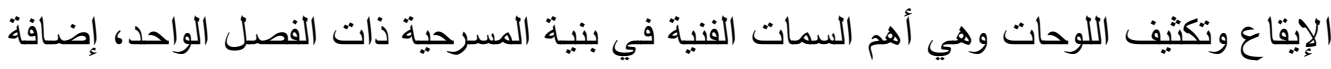

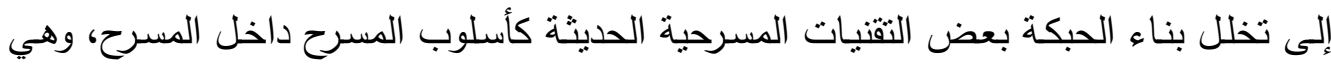

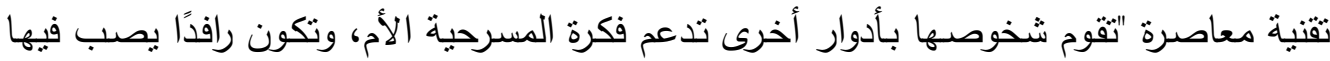

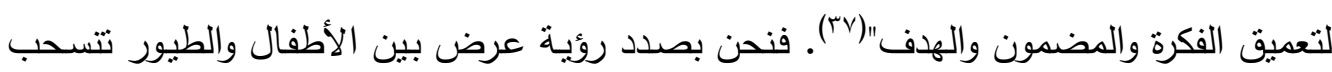

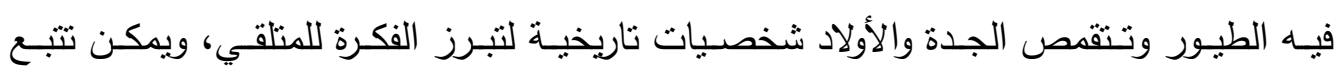
عناصر بناء الحبكة داخل النص كالتالي: تبدأ بوصول السنونو الكبير أخيرًا إلى مصر بعد رحلة هجرته يحط على أحد أغصـان

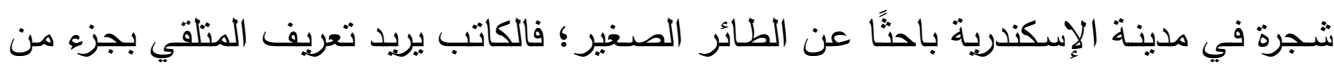

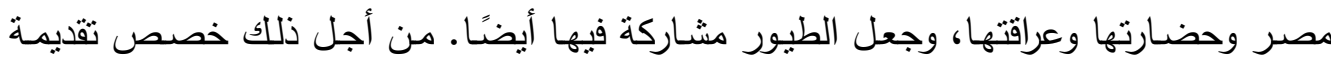
درامية طويلة نسبيًا بين الطيور المهاجرة التي تكثف عن جمال مدينة الإسكندرية كملجأ لهـ دائمًا بجوها وهوائها المناسب. تبدأ نقطة الانطلاق الحقيقية حينما يلتقي الطائران، ويقص أحدهم

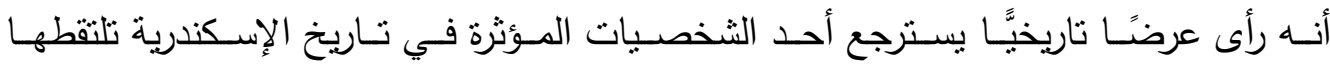
الثخصيات البشرية كنقطة لبداية الأحداث، وينتهي دور الطيور • بحيث يؤكدون أن مصر بَتَتْ

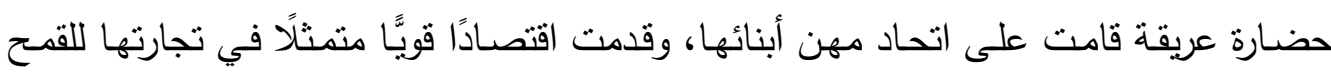

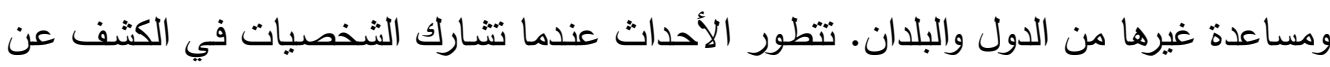

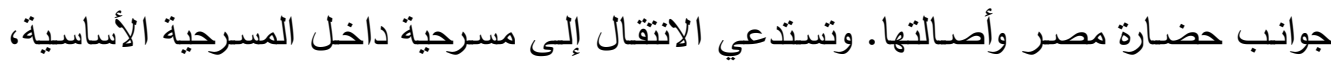
حيث يجسد الأطفال والجدة شخصيات تاريخية، يدخل أيمن في زي الإسكندر كحقبة تاريخية جديدة يضم مصر فيها إلى إمبراطوريته تتأزم الأمور عندما تدعو الجدة الإسكندر إلى احترام 
قدسية الأرض، والإله آمون. يتهكم من ذللك ويعتبره غير حقيقي؛ فاليونان بها من الآلهة ما

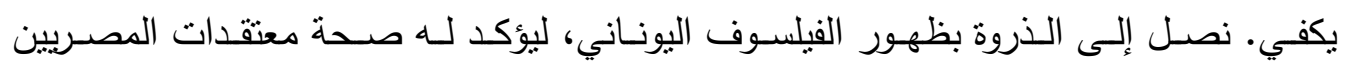

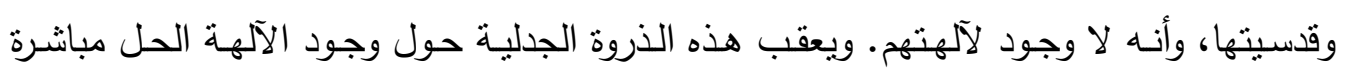
بدعوة الجدة والأطفال الإسكندر إلى عبادة الله. ب-بنية الحدث:مسرحية من فصل واحد يتتاسب فصرها مع مرحلة الطفولة المتوسطة، تعتمد

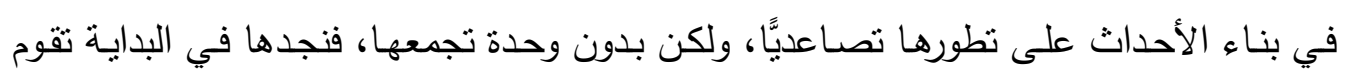

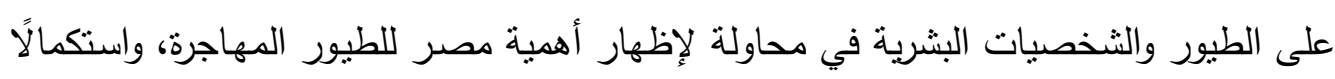

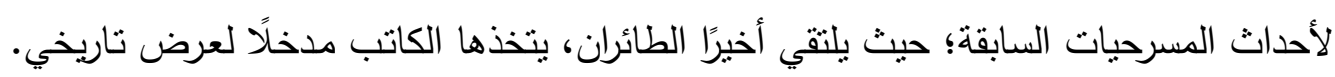

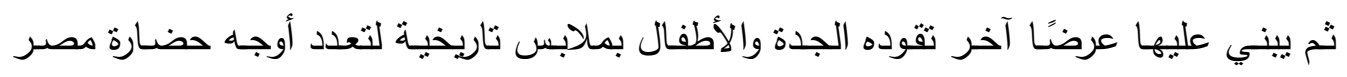
وأهميتها. ثم تتدفق الأحداث في تطور مع دخول أيمن في شخص الإسكندر . حتى نصل إلى

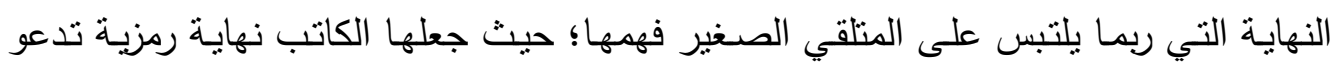

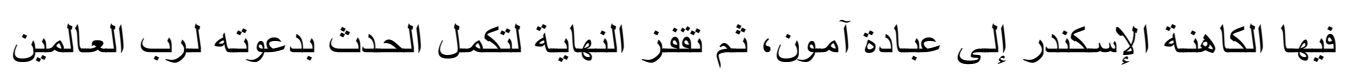
دون مبررات عن سبب وجود آمون. وذلك يرجع إلى رغبة الكاتب في ربط الماضي بالحاضر

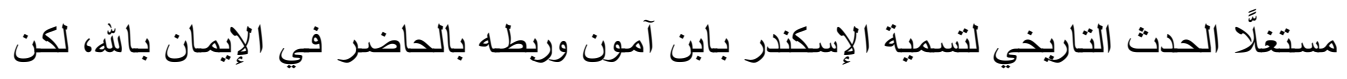

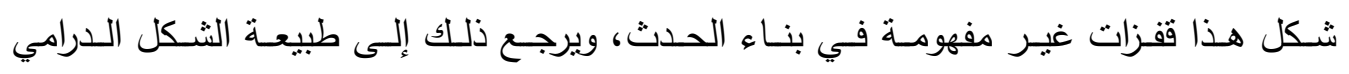

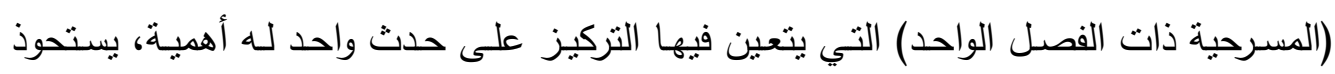
على انتباه المشاهد.

ج- الصراع الدرامي في المسرحية: الصراع داخل النص له بعدان: بعد فكري (داخلي) والآخر

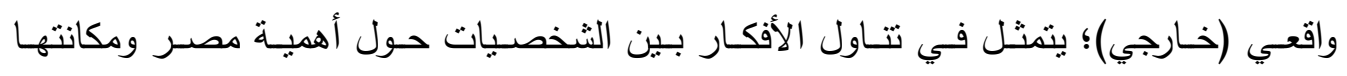

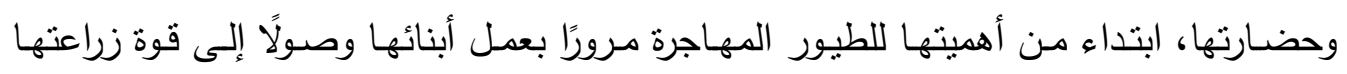

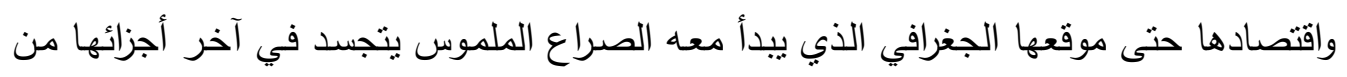
خلال المجادلة بين الثخصيات والإسكندر حول دخول مصر واستعمارها:

رغدة: جئت تهلم الجسور؟

رندة جئت تحرق القصور؟ الأم: يا ويلنا.. يا ويلنا شعب على شفا الخطر الإسكندر : بل شعبكم ... سيلتي 
يستتد كذلك على حرص الإسكندر على زيارة آمون ، فبنى عليها صراعًا آخر بين حوار الكاهن والإسكندر يدعوه فيه الكاهن للتوحيد في حين يسخر منه الإسكندر ، يدعم موقف الكاهن الفيلسوف اليوناني والجوقة مما ينهي الصراع لصالحهم. الإسكندر: من...؟ أحكيم اليونان الأكبر ... أنقني... جادل عني هذا الشيخ الثرثار

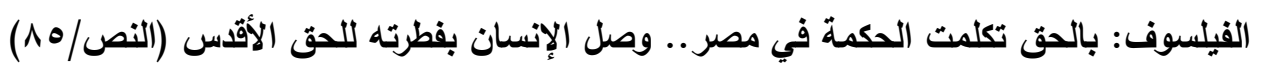

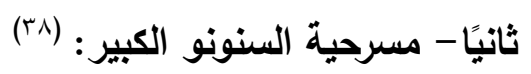
ا-عنوان المسرحية ودلالاته: العنوان مختزل في الشخصية المحورية داخل الخطاب، كما أنه ألصق بها صفتها. والعنوان يولد دلالات لدى المتلقي بأنه بصدد مغامرة بطلها طائر السنونو دون أن يفصح عن تفاصيلها تحقيقًا لإثارة المتفرج وتشويقه. Y - خطاب الكاتب القيمي في المسرحية/ (الفكرة): المقدمة المنطقية هي ذاتها هدف أوسكار وايلد(9) من قصة "الأمير السعيد" حيث يستتد على القيم التي تدعو إلى فعل الخير والتضحية وحب الناس والمسئولية الوجدانيـة، وهي في مجموعها قيم تربوبـة تتطوي على قيم اجتماعيـة وأخلاقية اختزلها في أفعال الأمير السعيد، وطائر السنونو: واجيه السنونو: أنتت الأمير السعيد تضحى بعينك تحرم أنت جمال الحياة، وسحر النظر الأمير: أضحي بعمري لأن الثقاء مرير وأن التقاعس عن نجدة الغير ...لا يغتفر (النص/ ؟ه) فالأمير السعيد بضحي بعينه ثم بما بغطي جسده من الذهب والفضـة لمساعدة الفقراء والمحتاجين حتى يصبح حطامًا دون تردد؛ والسنونو بوقته وتخلفه عن الهجرة. يقدم بهم مثالًا للأطفال في التضحية والعطاء فيذكر الأمبر (ولكني سأغدو.. حبيب القلوب.. ويبني لي الرب قصرًا رحيبًا ... بيوم القيامـة (النص/هV). كما أنه بطعم ثنايا الحوار بقيم قومية؛ فما زال هاجسه هو نتمية الانتماء وحب مصر وتقديرها لدى الأطفال ينتهز دائمًا الفرصة على لسان الثخصيات ليعبر فيها عن أهمية مصر ومكانتها: السنونو: هناك في مصر دفء الحياة ودنيا الشباب 
وشمس تمد علينا ثياب الأثعة تغمرنا بالحنان

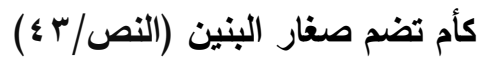
ب- لغــة الخطـاب وإيقاعـه: (المسـتوى اللفوي، الإيقـاعي، والتصـويري): كتبت بلغـة عربيـة فصحى، في قالب شعري وترتفع اللغة عن مستوى الطفولة المتوسطة بصورها وألفاظها؛ لذلك

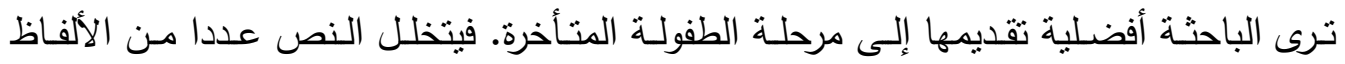

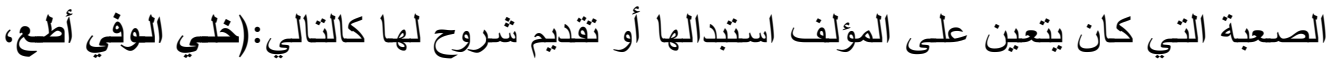
وحتى الهزيع الأخير، مجير، الجديب، مهادًا خصيبًا). كما أنها ثرية بالعديد من المفردات الفصئيل

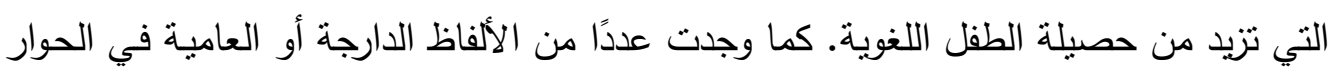

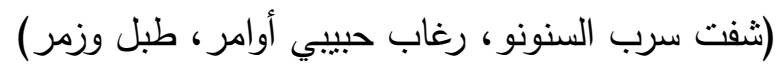

الـلالات الإيقاعيـة للخطـاب: يتشكل الإيقاع داخل النص على المستوى الخـارجي والداخلي بمجموعة من الوسائل المختلفة/ كالوزن والقافية: مثلت البحور الثعرية مصدرًا لتحقيق الإيقاع الخارجي كبحر المتدارك والمتقارب. أما عن عناصر تحقيق الإيقاع الداخلي فنجد: التكرار وقد تتوعت مظاهره من الحرف ثم الكلمة والجملة والصيغ، لأثرها الإيقاعي إضـافة إلى رغبته فئه في

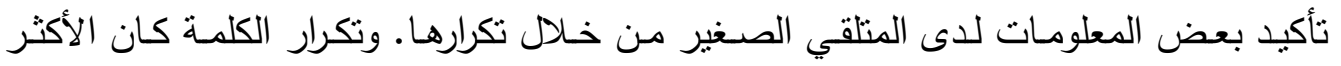

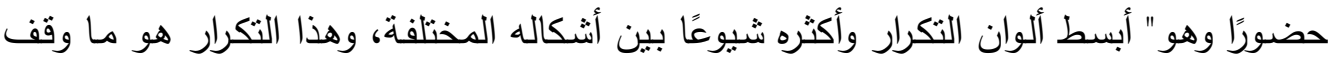

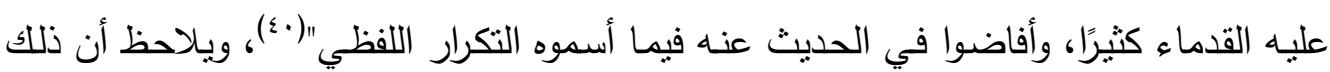
النمط من التكرار يتميز به أسلوب الكاتب، فهو يعتمده في كامل المجموعة المسرحية (هناك... هناك، يبكي ويبكي، عجيب.. عجيب، استمع.. استمع، بصوت سعيد.. سعيد). كما نجد أن تكرار الجملة لديه يقوم بوظيفتين: الأولى وهي تحقيق التوازن الإيقاعي والدلالات الخطابيـية (الأمير:

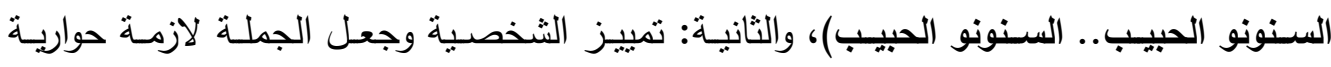

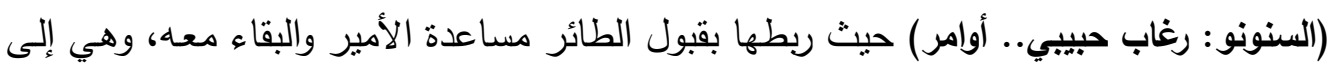
جانب وقعها الموسيقي تستدعي في ذهن المنلقي الحدث السابق عند تكرارها.

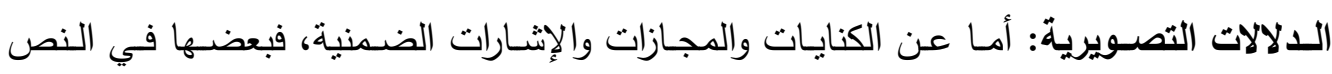
صعب الإدراك نذكر منها حوار الأمير : (وحين أرى الدمع بين العيون ...أحس بأن النجوم وأن

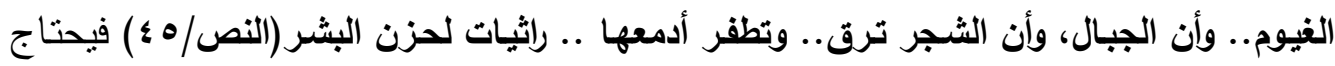


الطفل في البداية إلى تخيل وفهم كيف تريق عناصر الطبيعة دمعها، وتواسي البشر في حزنها،

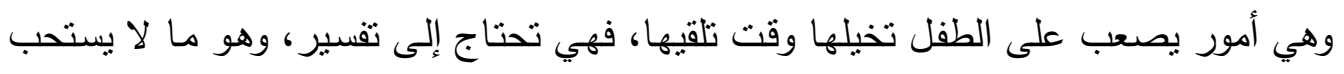

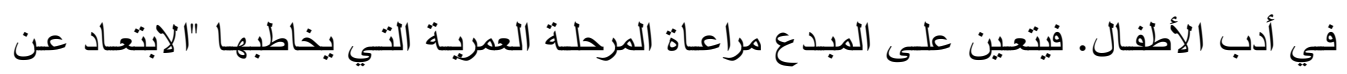
الأساليب البلاغية القديمة غير المألوفة، والعبارات المسكوكة المبتذلة، والجمل الطويلة، أو ذات

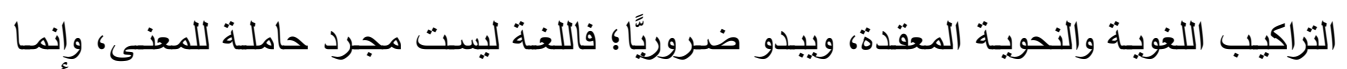

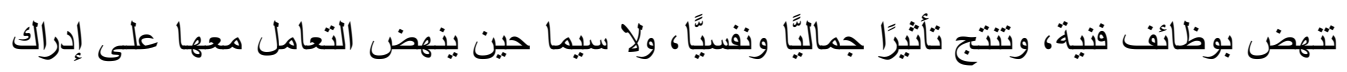

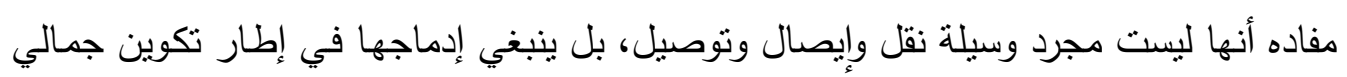

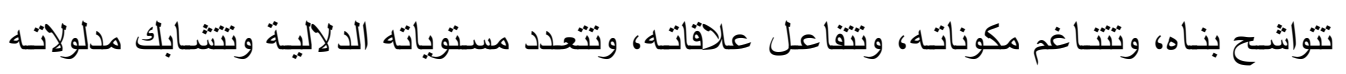

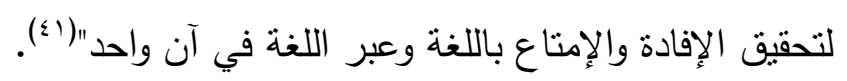

الأسلوب: يتميز الأسلوب في النص بتكثيف الإيقاع الناتج من دفع الحدث للأمام من خلال نموه وتطوره. كما اعتمد في بناء الجمل على التتوع بين الأساليب اللغوية، منها الإنشاء مستقيدًا

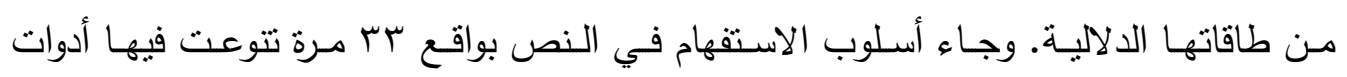
الاستقهام وأغراضـه. فمثنًا: (أين صديقي الحبيب؟ أحزنًا تكابد؟ مـاذا ستفعل؟، بماذا؟، مـاذا..

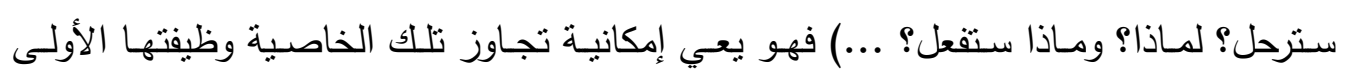
المباشرة من طلب التقرير والاستعلام إلى أغراض بلاغية متعددة.

ـ - أثـكال الخطـاب الـدرامي (الحـــوار): بَنَت الحـوار على الجمـل القصـيرة سـريعة الإيقـاع والمتبادلـة بين الثخصيات، وفي بعض الدقاطع الحواريـة التي تعبن الثخصية على تقديم

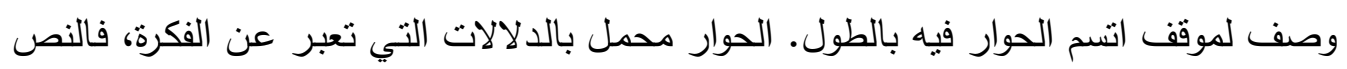

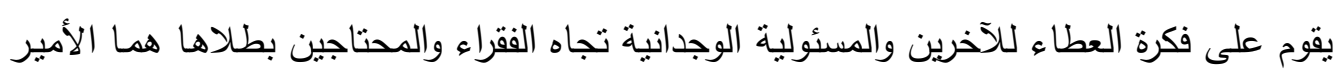

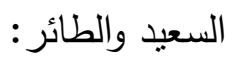
الأمير : وكيف أكون سعيدًا وعيناي تخترقان الشوارع تسترقان حكايات البيوت وتستمعان رزايا الزمن فأشهر مأساة كل البشر رئر الزمن

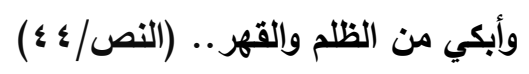


فالحوار السابق يعبر عن حزن الأمير وإحساسـ بالغير ، فلا يشعر بسعادة والمدينة تعج

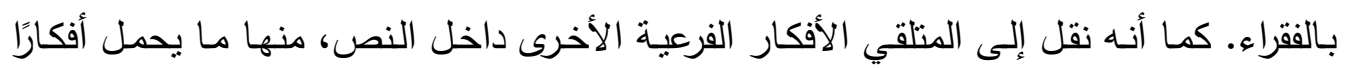
ونظرات فلسفية للمؤلف. كما كثف عن الثخصيات وأبعادها النفسية وعلاقتها الاجتماعية. التنـاص: تتوعت صسور التتاص داخل الخطاب كمـا تتوعت أنواع ذلك التضمين في المحور

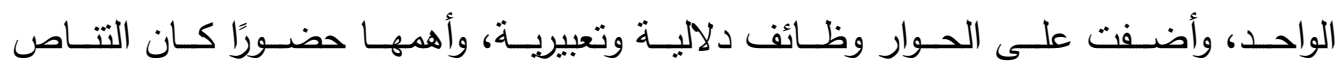
الايني والأدبي.

التناص الديني: التتاص في النص غير مباشر "فهو الذي يستتبط من النص استتباطاً، ويرجع

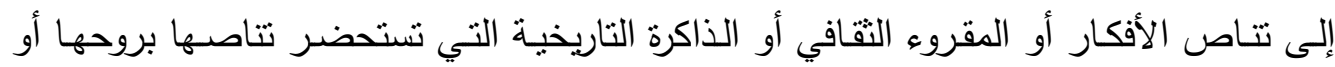

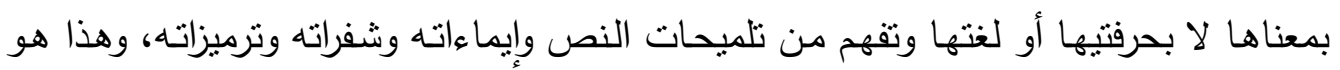

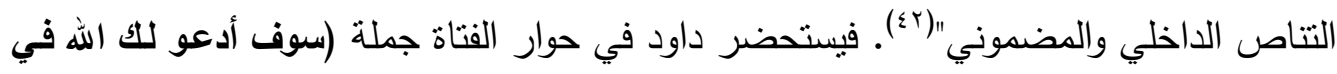

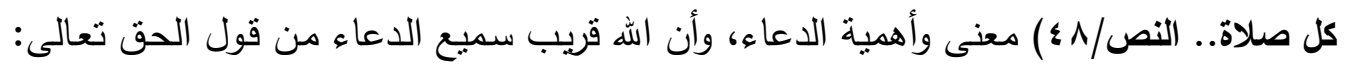

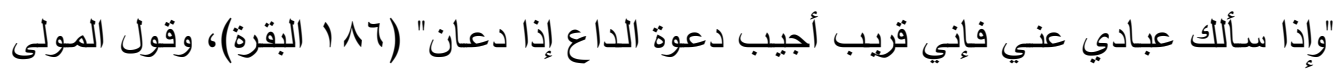

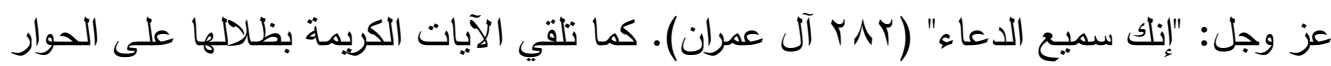

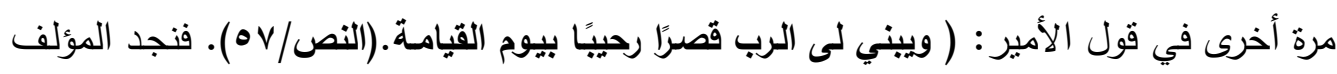

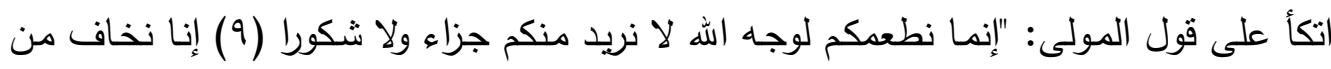
ربنا يوما عبوسا قمطريرا" (9 الإنسان) فهو يقدم المساعدة ليس لمقابل مادي، وإنما طمعًا في لهي

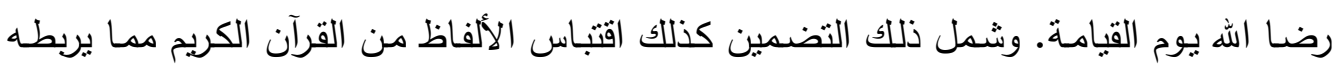
دلاليَّا بنص الاقتباس ومعنى الآيات:

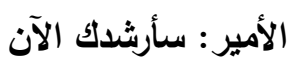
كيف تنتزع هذي الشرائح عن جسدي في الانتار كيف توصلها لبيوت المدينة كل العجائز، كل الصغار

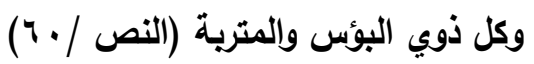

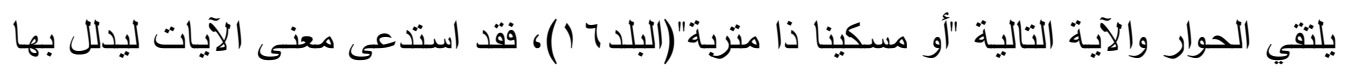

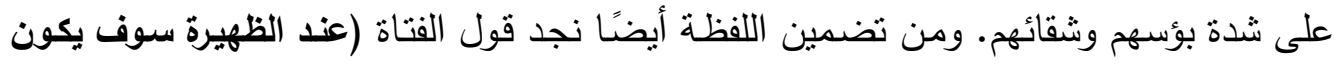

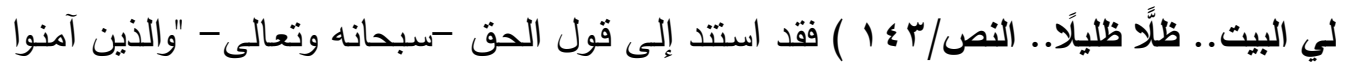

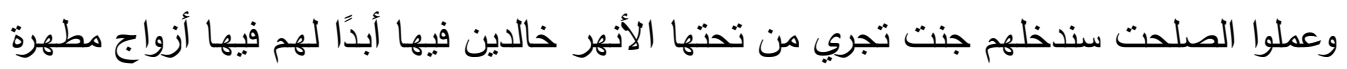
وندخلهم ظلا ظليلا" (النساء/OV). 
التنـاص الأدبـي: القصـة الأساسية للمسرحية هي القصـة الأصلية "لأمير السعيد" أبقى على

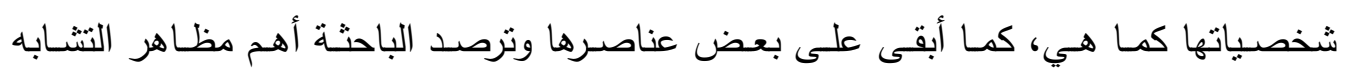

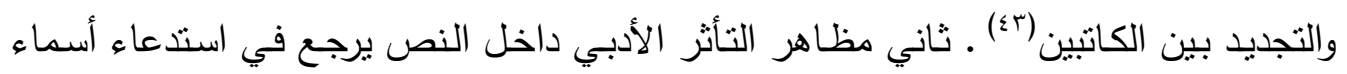

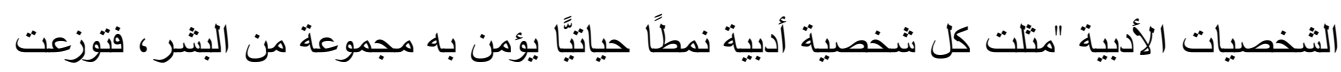

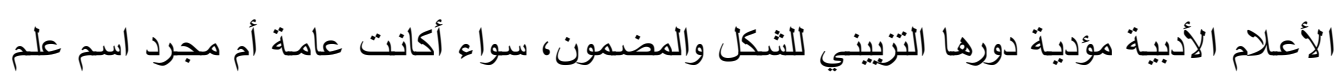
تتطق به الثخصيات"(؛ ؛). فيقول الطائر السنونو: هناتك قيس وليلى بهن وروميو وجوليت الأمير : أحاديث تعذب وجولث عند السمر ولكنها في صراع الحياة وأهوالها..

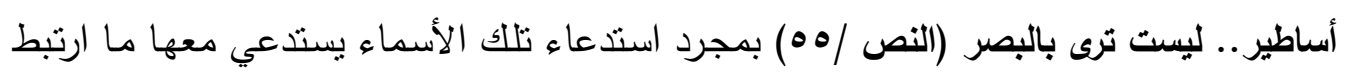

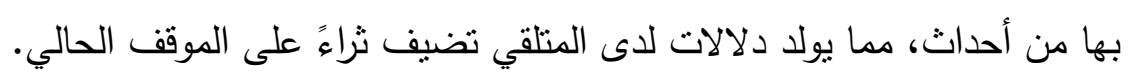
ه- خطاب الإششادات المسرحية:شكلت التوجيهات الخاصة بالحركة والمشهد أهمية كبيرة، مع خلو النص من وجود إثارات أخرى ترتبط بالعناصر الفنية، وإن وجدت فهي تعليمات قليلة. 1- وصـف الثخصـية: شـخلت توجيهات الحركـة الجزء الأكبر في إرشـادات الثخصـية؛ المسرحية تعتمد على حركة طائر السنونو وتوزيعة لمجوهرات الأمير على الناس محورًا أساسيًّا

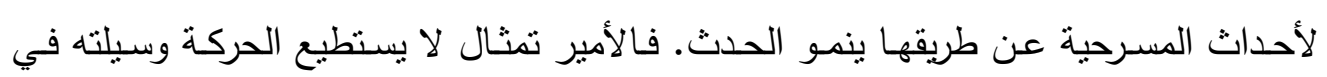

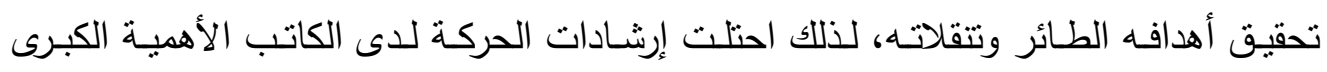

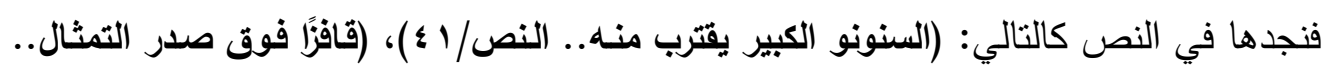

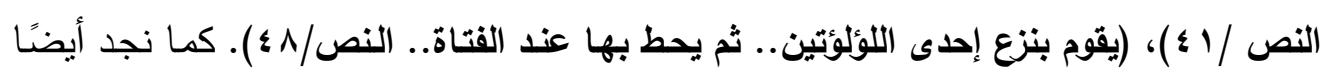

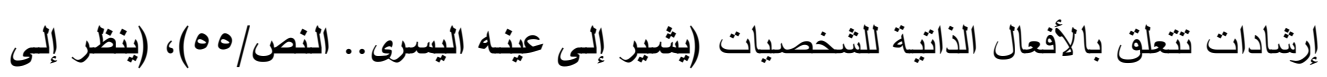

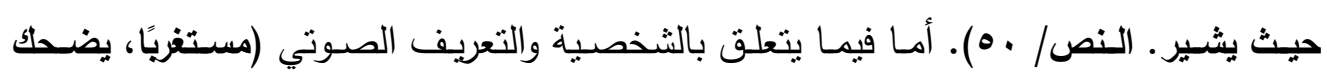

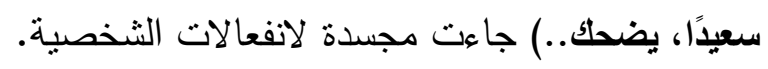

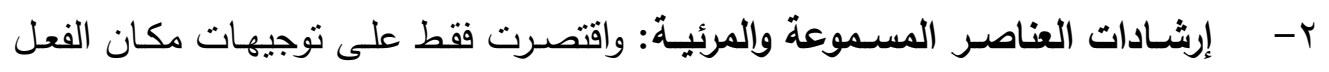
ووصف بعض أجزاء المشهـ، ونجد الكاتب قدمها على مشهدين الأول: (ســاحة متراميسة الأطراف.. في إحدى المدن الأوربية.. الوقت ينذر باقتراب الثتاء.. على قاعدة مرتفعة ينهض الثض 
تمثال " الأمير السعيد".. النص/1 ؛). الثاني: (يتغير المنظر.. جوقة من الطيور والأطفال.. أمام

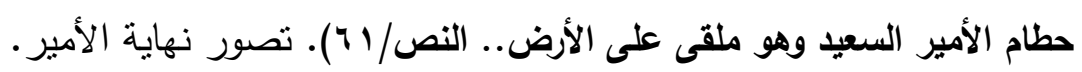

צ- خطاب الشخصبات في المسرحية: استتد إلى عدد قليل من الثخصيات وهما شخصيتان

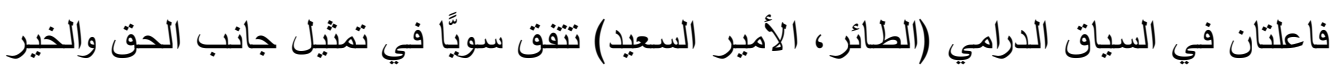

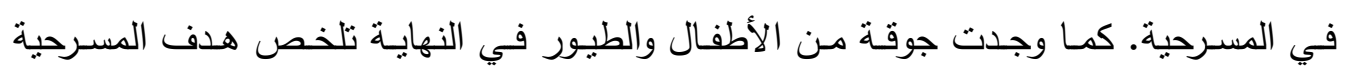
ونهايتها. بالإضافة إلى عدد من الثخصيات الخاملة، وهي (الفتاة والثاب). الأمير السعيد: (رئيسية) شخصية غرائيية، كان أميرًا لمقاطعة ما في أوروبا، لم يعرف الثقاء

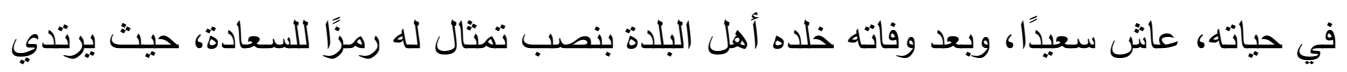

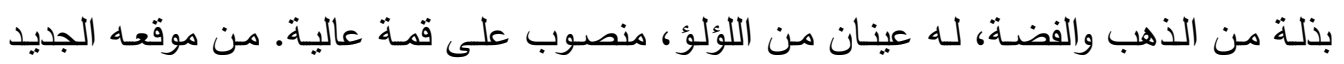

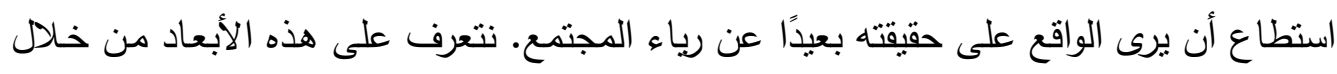

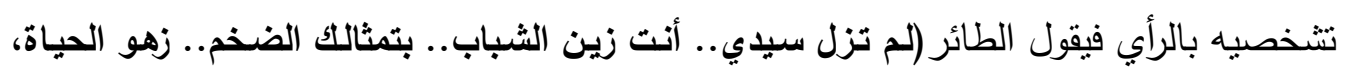

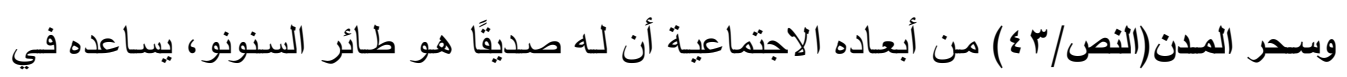

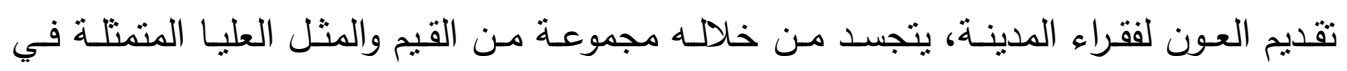
المسئولية الأخلاقية ومساعدة الآخرين.

تتحول الثخصية داخل الخطاب على مستويين: أ- الخارجي/ الفيزيقي: من الهيئة الجيدة

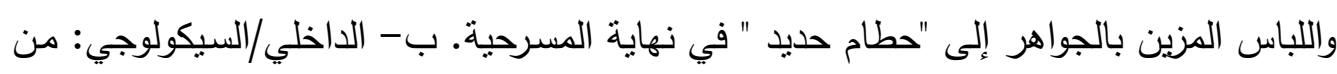
الثقاء والتعاسة نتيجة شعوره بالمحتاجين وعدم قدرته على مساعدتهم إلى السعادة والراحة؛ لأنه أسعدهم، ويعلم أن الجنة تتنظره جزاء ذلك. تلك المفارقة تتقل للمتلقي مفاهيم عدة تتعلق بالسـلام والرضى الداخلي. كما أن اسم الثخصية يحمل مفارقة بينه وبين مضمون الخطاب الحكائي

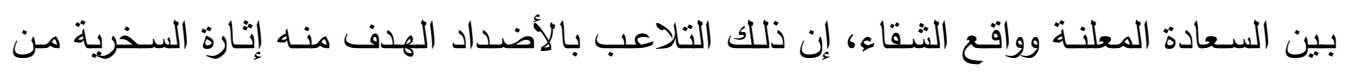
المتمعات التي لا تقوم على العدالة الاجتماعية.

طائر السنونو: (الشخصية المحورية) شخصية غرائبية، إحدى طيور السنونو التي تهاجر إلى

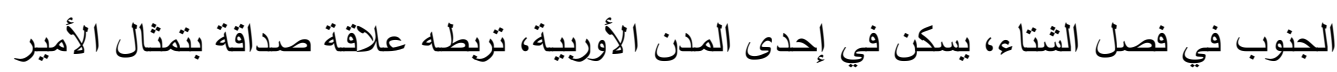

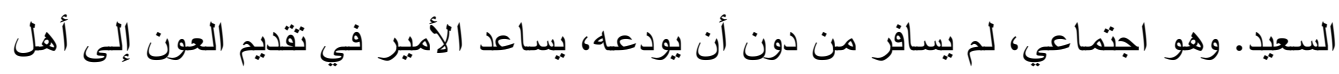

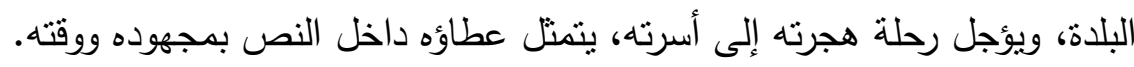


مرجعية خطاب الشخصيات: يتم دراستها على مستوى بناء الضمائر الذاتية والفضاء الدرامي.

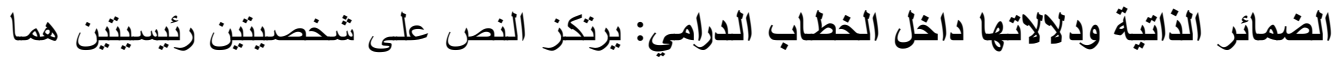

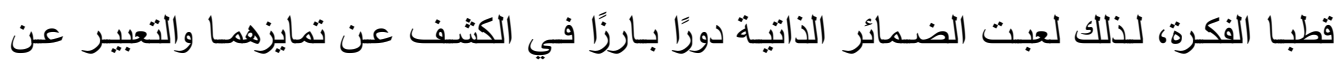

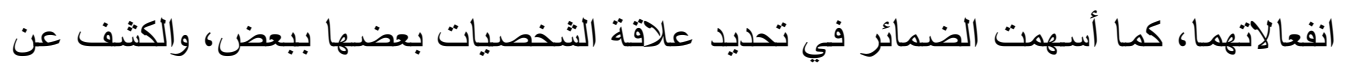

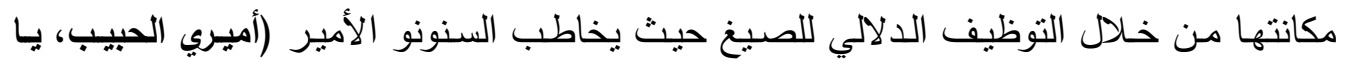
سيدي) والأمير للطائر :(العبيب، أخلص الأصدقاء) التي تكثف عن العلاقة الطيبة الودية بين

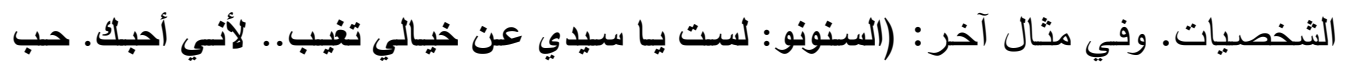
السنونو وفاء وطيب. (النص/ إ؛) ربط الضمير المنفصل والمتصل معًا يجعل شخصية الطائر

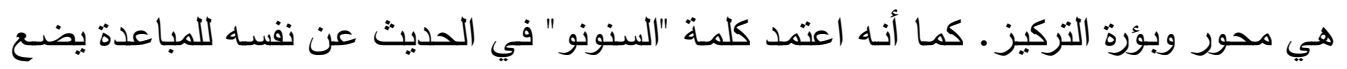
بها مسافة بينه وبين ما يتحدث عنه لجعلها تتسم بالموضوعية والثمولية.

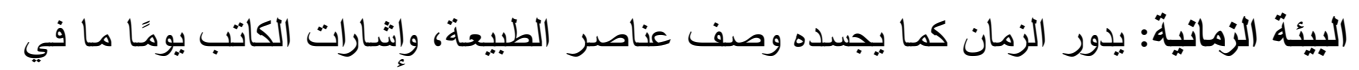

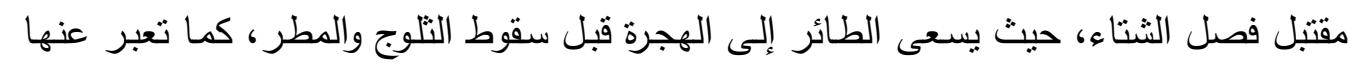
الشخصيات داخل النص كالتالي: السنونو: سيقترب الثلج ويغدو الجليا

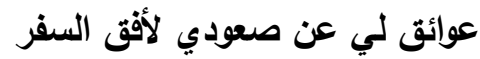
أخاف إذا ما تأخرت أكثر عي عن لأن يجيء الثتاء العنيد

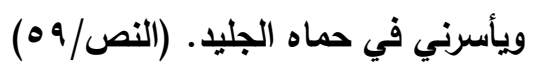
البيئة المكانية: تدور الأحداث في إحدى ساحات المدن الأوربية على قاعدة مرتفعة حيث يوجد تمثال الأمير • توجد إثارات متفرقة إلى المدينة وشوارعها وبيوتها: الأمير : تعال هنا. اعل رأسي. وانظر ... هناك... على المنحدر

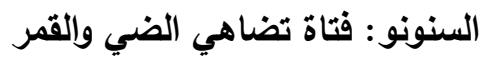

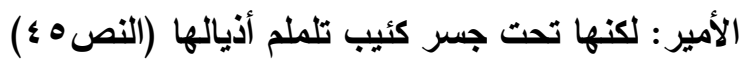

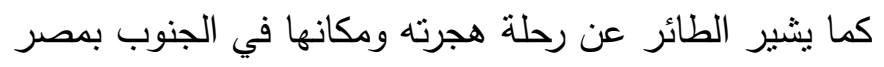

V- آلبات البنية الارامية: بنى الكاتب أحداثه في خط متصاعد يعتمد على عقدة واحدة بسيطة

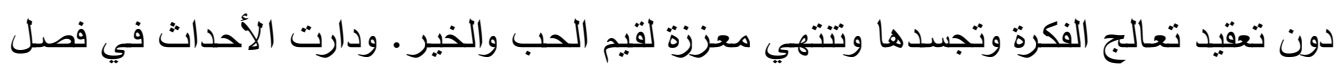

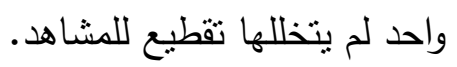


أ- العبكة: طبيعـة المضمون يقوم على تقديم عدد من القيم التربويـة مختزلة في شخصيتين دراميتين على أفعالها ينمو الحدث. مدا أثر في بناء الكاتب للأحداث التي اتسمت بالتكثيف لتهن والتركيز انعكس ذلك على حبكته الدرامية التي اتسمت بإحكام بنائها وتوافر عناصرها بطريقة تجذب المتلقي، كمـا أنها حبكـة بسيطة تعتمد على عقدة واحدة تنتاسب وقصـر المسـرحية

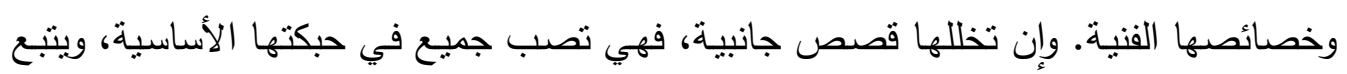
في بنائها الأسلوب الأرسطي. من بداية مع رحلة طيور السنونو في الهجرة إلى مصر ، حيث سافرت مجموعة، تخلف عنهم أحدهم لرغبته في وداع صديقه الأمير السعيد، ذلك التمثال القائم

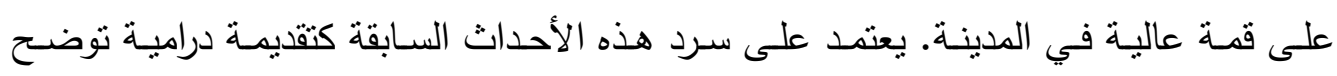
الموقف الحالي. ونقطة الانطلاق الحقيقية في وداعه لصديقه الأمير يلمح في عينه حزنًا عميقًا

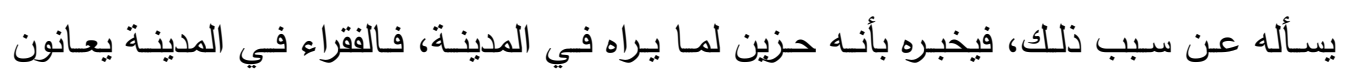

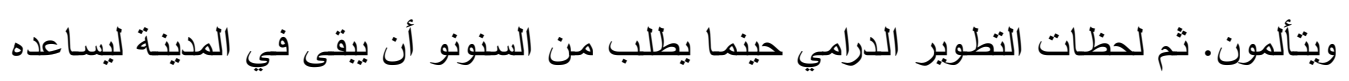

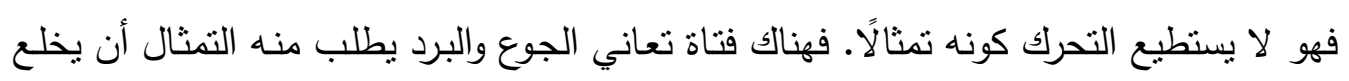

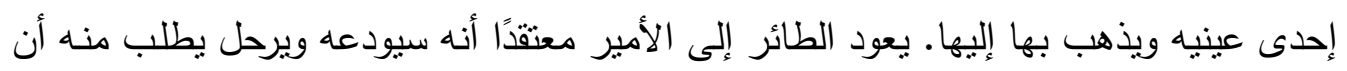

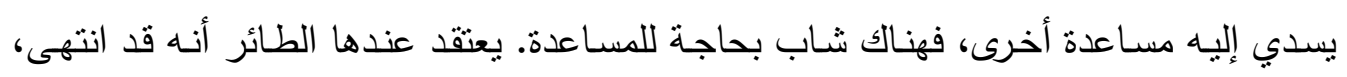

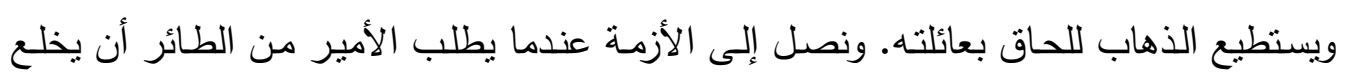

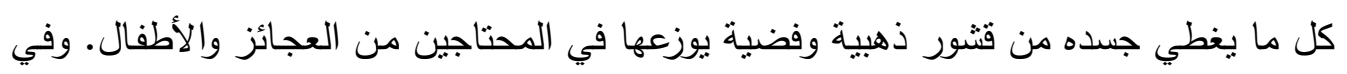

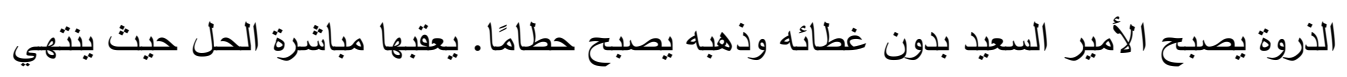
الأمير السعيد إلى حطام، في حين بسافر الطائر إلى مصر . ب- الصراع الدرامي: هو صدام بين الفرد وبرجوازية المجتمع وريائه. ولكنه صراع غير ملموس يجسده الأمير بنوازعه الداخلية التي تظهر في شقاء روحه وتعاسته على الرغم من كونه رمزًا

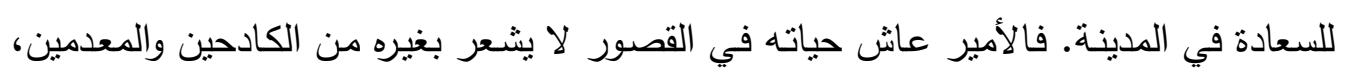

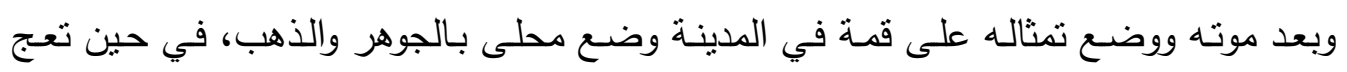

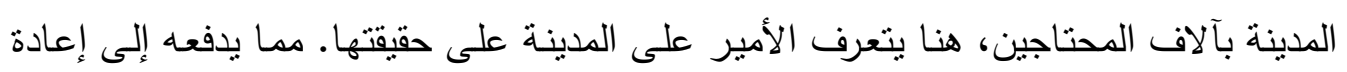
توزيع ما يمتلكه. يستعين في ذللك بالطائر الذي يوزع الثرائح على المدينة، وينتهي هذا الصراع بانتصار الأمير السعيد وتحقيقه السعادة والسلام الداخلي لنفسه حتى وإن أصبح جسده حطامًا. 


\section{نتائج تحليل النص:}

- ت تلوعت خطابات الكاتب أنس داود في مسرحياته الثـعرية للطفل، وتتقسم المضـامين

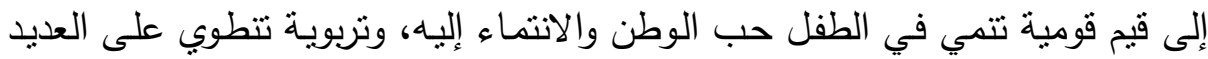

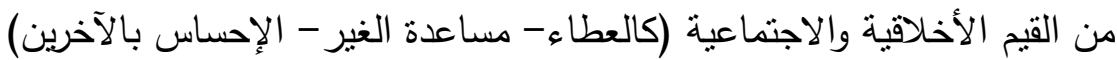
- لخطاب العنوان دلالة واضحة كما أنه بدور حول الثخصية المحورية.

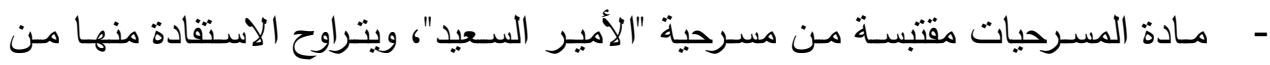

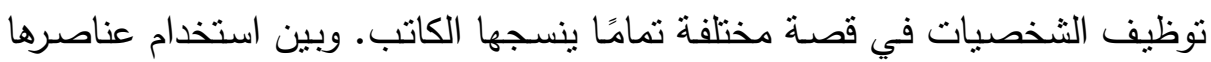
الأساسية من فكرة وشخصيات كما في مسرحية السنونو الكبير ، كما أن النهاية عالجها

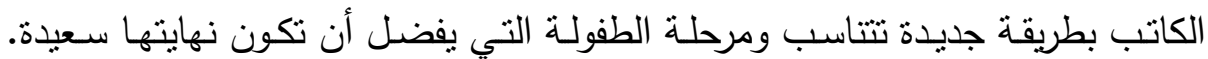
لذلك تتتهي المسرحية دون أن يموت الطائر .

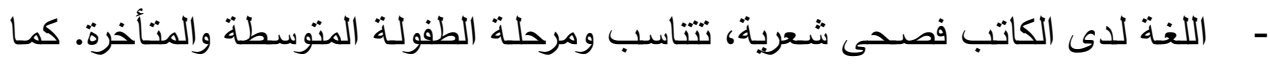

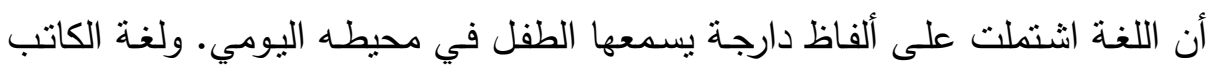

محملة بالمعاني التي تزيد من ثراء معرفة الطفل بالعديد من المفردات حول الفكرة.

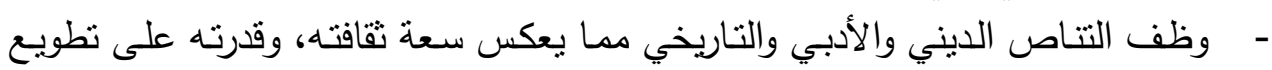

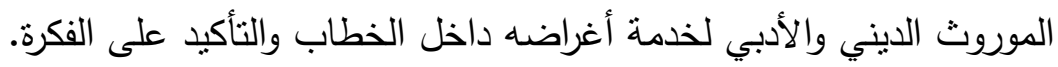

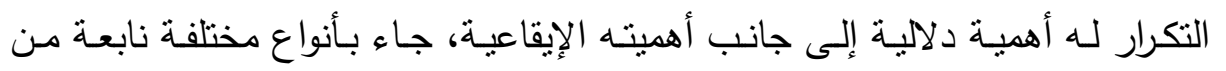
الثخصيات، ومنوافقة مع السياق، وملائمة للمرحلة المخاطبة.

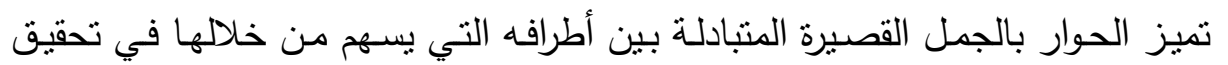
نمو الحدث وتطوره.

- - يقدم الكاتب الإرشادات المسرحية كخطاب مجسد لفعل القول.

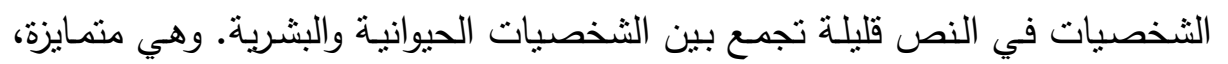
تتوافق أفعالها مع توجهها نحو الخطاب المعروض، كما تتميز الثخصيات بات بالتجانس.

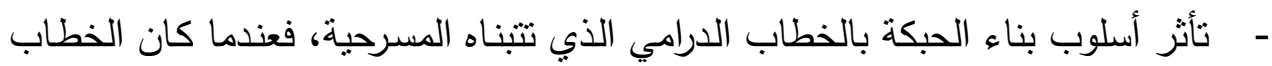

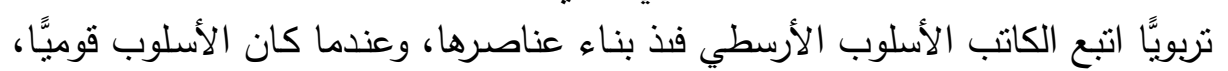

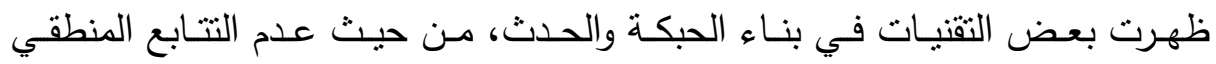
لوحدات الحدث، واستخدام أسلوب المسرح داخل المسرح.

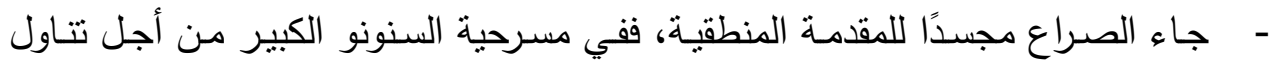

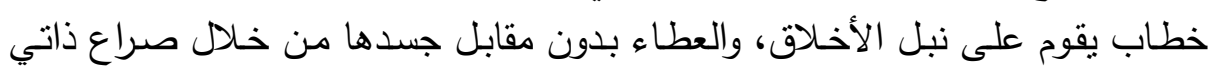

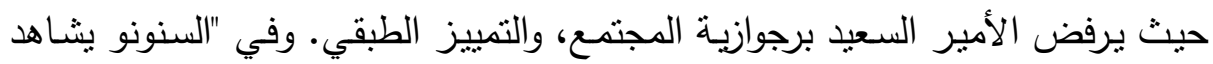

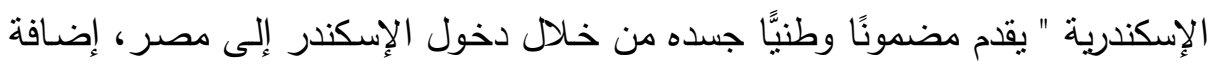
إلى جدلية الأفكار بين الثخصيات التي تعدد مظاهر حضارة مصر . 
(1)Barbara D. Stoodt, Linda B.Amspaugh and Jane Hunt (1996). Children's Literature, Gorsuch Scarisbrick ,p29, Australia.

(2)Asterios Tsiaras (2016). Teaching poetry through dramatic play in Greek primary school: Surveying teacher's and pupil's views, New Zealand journal in performing arts and education, vol 6, p 38

(3)Yahy Saleh Hassan (2016). Yeats: Resurgence of poetic drama in the twentieth century, Al Baha University, Tieba Journal , , vol 5, n. 9 ,p. :1213. Suadi Arabia

(4)Nye Russel (1963). Modern essays, Glenview, p:303 Scott. Foresman and Company.

(5)Benton. P. (1984): Teaching poetry: The rhetoric and the reality, Oxford Review of Education, vol 10(3), p319-327

(6)Goodwyn, A. (1992). English teachers and the cox models, English in Education, vol 26(3) ,p 4-10.

Powell, R. (1999). Literacy as a moral imperative: Facing the challenges of a pluralistic society. Lanham, MD: Rowman \& Littlefield.

(7) Jonathan Bolduc (2009). Effects of a music program on kindergartner's phonological awareness skills, International journal of music education, p27-37

(^) إحسان فهمي (919 (1). "شعر الأطفال وعلم النفس"، الحلقة الدراسية الإقليمية لعام 919 احول الثعر للأطفال،

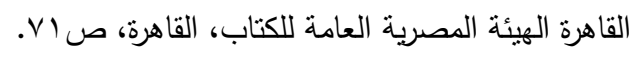

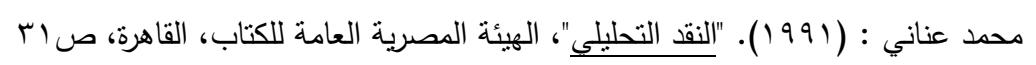

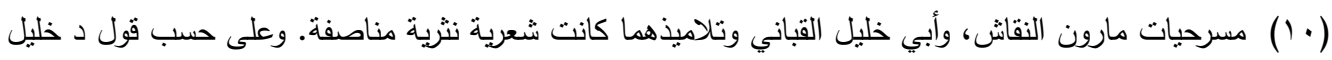

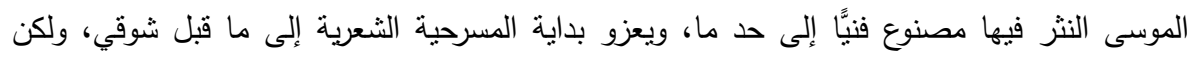

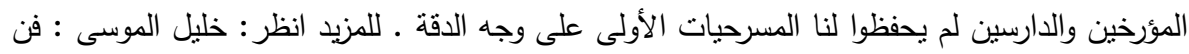

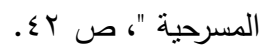

(1) للمزيد انظر: شمس الدين الحجاجي: (1990)." المسرحية في الأدب العربي الحديث"، دار الهلال، القاهرة،

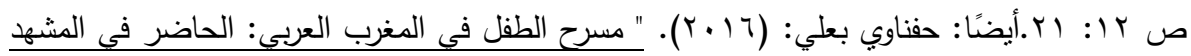

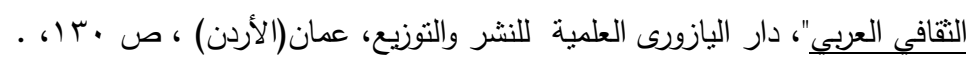

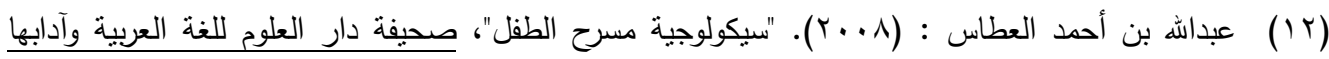

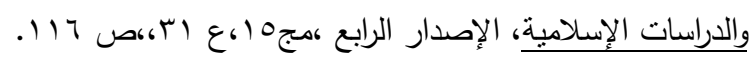

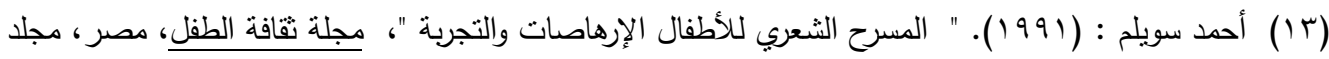

$$
\text { 7 }
$$

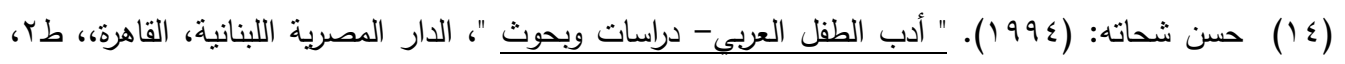

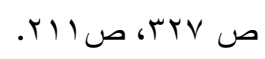

(0) إبراهيم شعراوي: " الذئب أوبريت غنائى للأطفال "، النص الحائز بالجائزة الأولى في مسابقة الأوبريت بعام

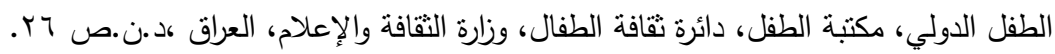

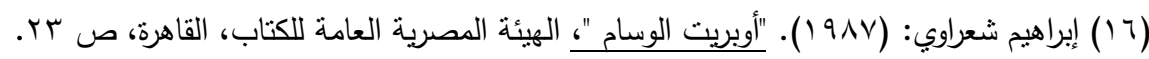

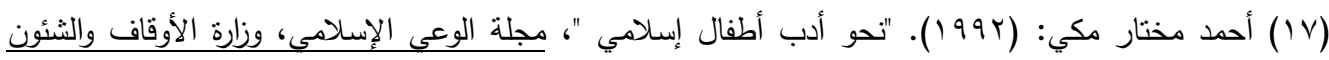

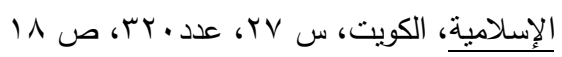

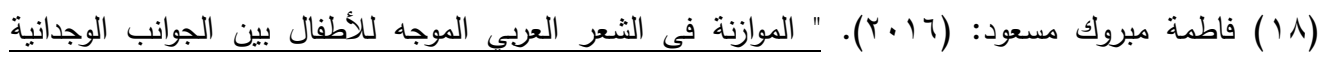

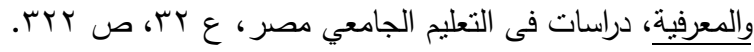

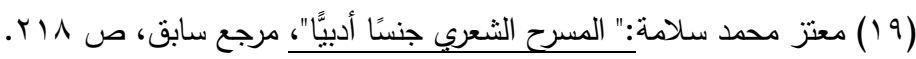




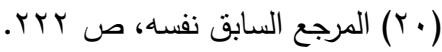

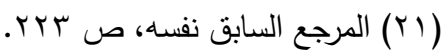

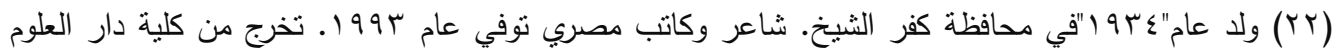

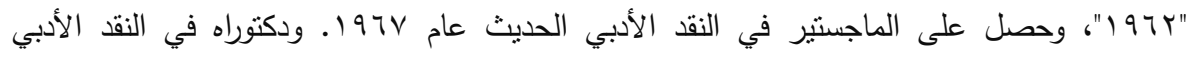

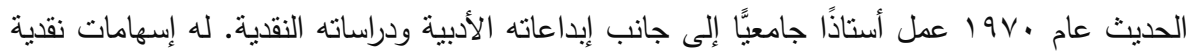

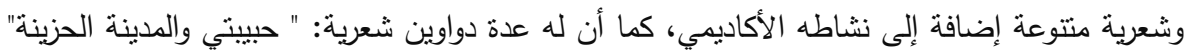

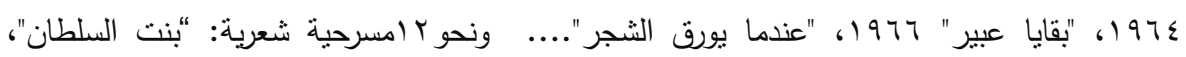

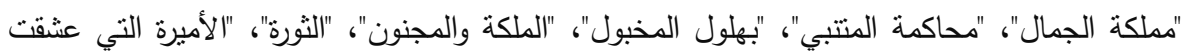

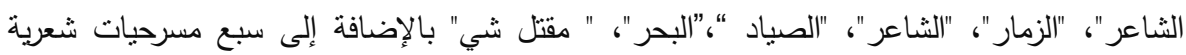

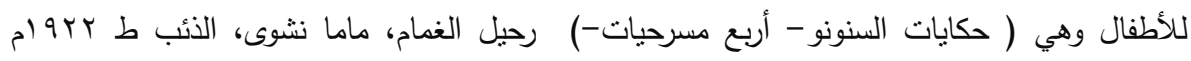

$$
\text { ومؤلفات أخرى. }
$$

(Yr) إخلاص عمارة: (1991). " مسرح أنس داود، عالم الكتاب، الهيئة المصرية العامة للكتاب، مصر ، العدد آس،

$$
\text { ص } 9.1 .90
$$

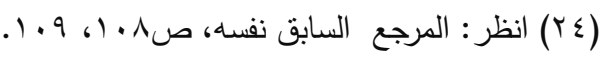

(Yo) (Y) (Yثير الكاتب في مقدمة مسرحية ".. يصادق أيمن "إلى كونها مقتبسة من قصة الأمبر السعيد للأديب

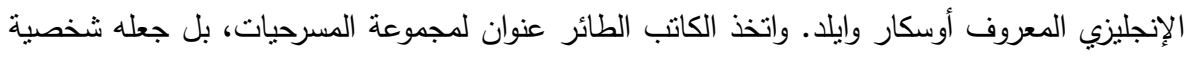

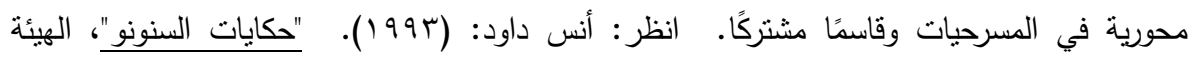

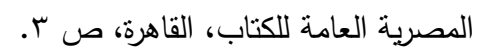

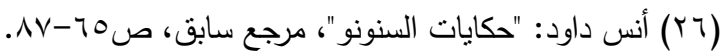

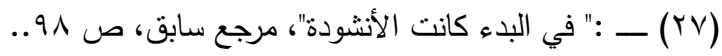

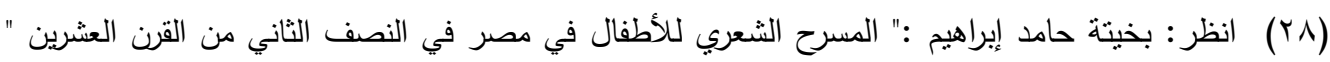

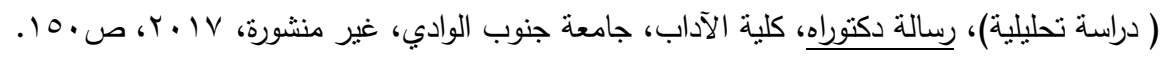

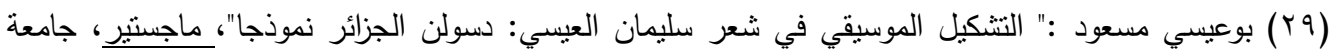

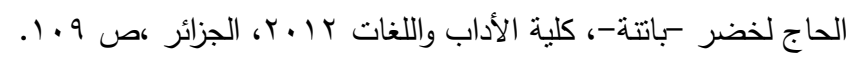

(r) ريم محمد طيب الحفوظي:" الدراما في الثعر تقنيات التشكيب ومسرحة القصيدة - الثاعر محمد مردان

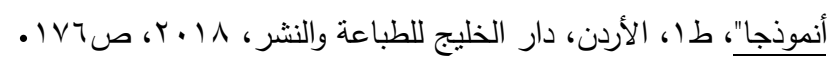

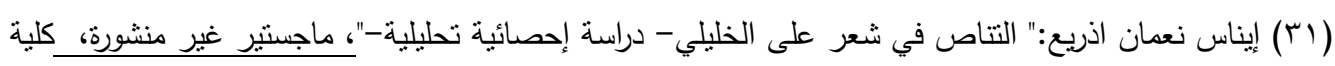

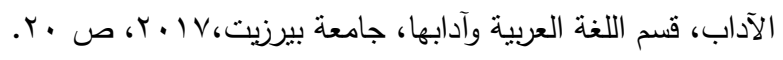

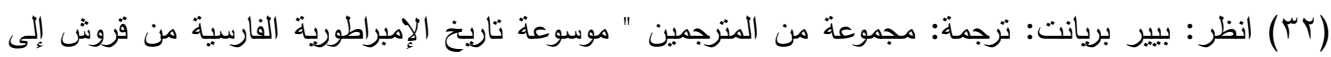

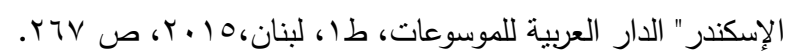

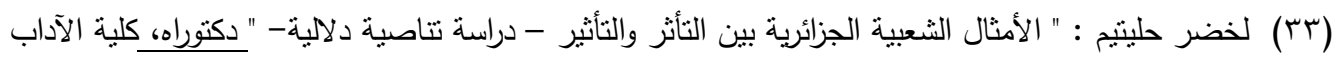

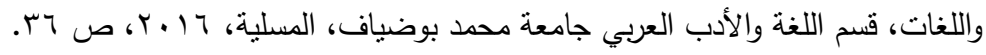

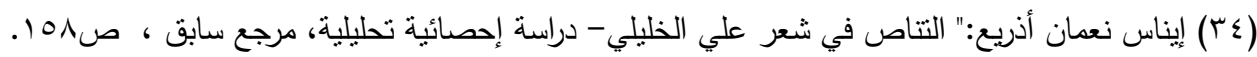
(0ץ) ناصر معماش :" بنية الصورة الثعرية ودلالات الرمز في الشعر الموجه للطفل في الجزائر"، رسالة دكتوراه،

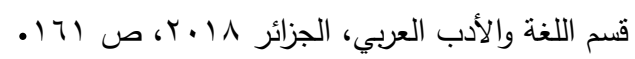


(דץ) محمد خضر عربف:" الوظائف الخطابية للضمائر العربية مع دراسة مقارنة لنظام الضمائر في كل من العربية

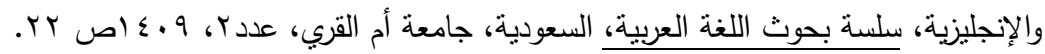

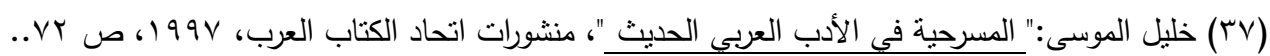

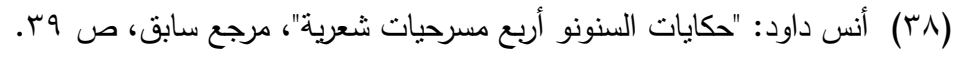
See: Oscar Wilde:" The Happy Prince and other Tale", second Edition, London, (rq) David Nutt, 1889, pp3-24 (•) عبد القادر علي زروقي:" جماليات التكرار ودينامية المعنى في الخطاب الثعري نماذج من شعر محمد بلقاسم

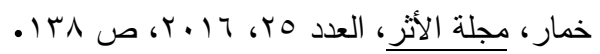

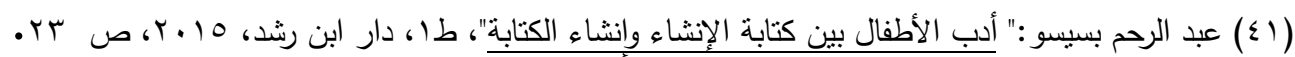
(Y؟ ) خليل يرويني، نعيم عموري:" التتاص القرآني في رواية حكايات حارتتا لنجيب محفوظ"، آفاق الحضارة

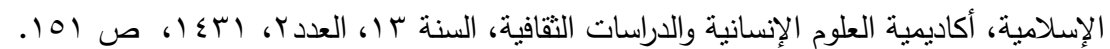

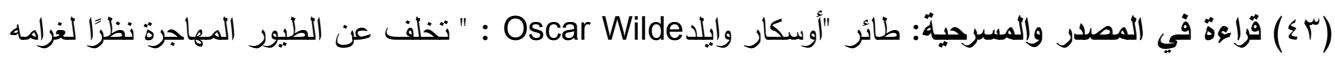

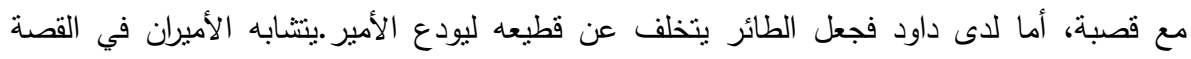
الرئيسية والمسرحية في سبب حزنه على ما يراه من شقاء للمحتاجين في المدينة. يفقد الأمير كلتا عينيه

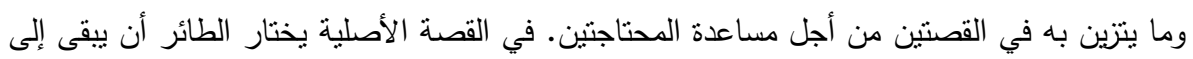

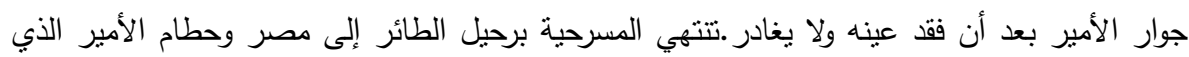

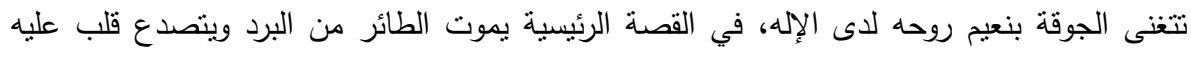
الأمير • اعتمدت الباحثة في تحديد أوجه الثبه والاختلاف بينهم على المراجع التهب التالية. انظر : أوسكار

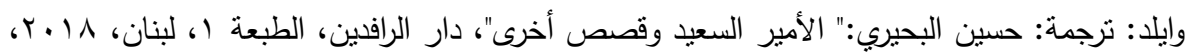

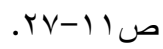

See: Oscar Wilde:" The Happy Prince and other Tale”, second Edition, London, David Nutt, 1889, pp3-24

(؟ ) بخيتة إيراهيم: "المسرح الثعري للأطفال في مصر في النصف الثاني من القرن العشرين - دراسة تحليلية"

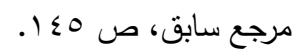

